\title{
Morphology, biology, phenology and occurrence of the genus Empis Linnaeus (Empididae, Diptera) in Poland
}

\author{
Stefan NIESIOŁOWSKI \\ * Department of Invertebrate Zoology and Hydrobiology, University of Łódź, Banacha 12/16, 90-237 Łódź, Poland; \\ e-mail: niesiol@biol.uni.lodz.pl
}

\begin{abstract}
Species of the genus Empis L. (Diptera: Empididae) of Poland are revised. A total of 47 species is recognised, 16 of which are recorded from Poland for the first time. Detailed information on morphology, biology, phenology and zoogeography are given.
\end{abstract}

Key words: Diptera, Empididae, Empis, morphology, occurrence, biology, phenology, Poland

\section{INTRODUCTION}

Dipterans of the genus Empis L. occur on all continents, yet they are most abundant in colder regions and in mountains. Out of 4000 Empididae species identified in the world about 300 have been recorded in Europe (Chvála \& Wagner 1989, Chvála 1999, Smith 1997, Schumann et al. 1999, Yang et al. 2004). Most data concerning Poland originate from old, usually dated in the $19^{\text {th }}$ and early $20^{\text {th }} \mathrm{c}$., faunal records that require verification (Palaczyk 1991). Although the above-cited authors carried out a limited verification of these records and questioned certain identifications, most of the respective collections have been lost or seriously damaged and their verification is rather impossible today. Consequently, they are mostly of only historical importance.

\section{DEGREE OF KNOWLEDGE}

Contemporary data on the genus Empis occurrence in the area of Poland are very few and fragmentary and usually originate from records of various dipteran groups or insects in general, collected in a given area (Szadziewska 1977, Szadziewski 1983, Klasa et al. 2000, Palaczyk 2001, Palaczyk \& Klasa 2003). No study exclusively devoted to the genus Empis from the area of Poland exists. Very rich and diverse literature on the above mentioned subject has been published in Europe (Engel 1938-1956, Collin 1961, Wéber 1975, 1981, Syrovátka 1980, 1991, Straka 1981, 1999, Hippa et al. 1981, Chvála 1978, 1981, 1991, 1994, 1996, 1997a, 1997b, 1998, 1999, Syrovátka \& Chvála 1986, Chvála \& Wagner 1989, Volkart 1991, Wehlitz 1992, Chvála \& Barták 2000, Meyer \& Filipinski 1998, Preston-Mafham 1998, Barták \& Roháček 1999, Schumann et al. 1999, Tulowitzki et al. 1999, Grootaert et al.2001, Grootaert et al., 2004). Consequently, it seems necessary to at least partially fill this gap, for which the present study is intended.

\section{GENERAL CHARACTERISTIC}

The genus Empis, together with the genera Rhamphomyia and Hilara, belongs to the subfamily Empidinae of the family Empididae of the suborder of short-antenna dipterans 
(Brachycera). The genus Empis consists of species that are characterized by both small body size (about $2 \mathrm{~mm}$ in length) and large body size (about $10 \mathrm{~mm}$ in length), which locates them among the largest dipterans occurring in Poland. The dipterans are mostly black, blackbrownish, occasionally yellow or yellow-brownish, especially those of the subgenus Xanthempis. A characteristic feature of males is that their first and third leg pairs are abundantly haired while setae of females are "feather-like" in shape. This is related to their mating behavior.

\section{MORPHOLOGY OF THE ADULTS}

Their head is rounded, usually elongated, with large eyes which in males are holoptic and characterized by diverse ommatidia, decisively larger in the upper part. The ommatidia of females are smaller and always of the same size. In the subgenus Xanthempis (Fig. 1) the eyes are small and dichoptic. Also in the subgenus Pachymeria and in several species of the subgenus Polyblepharis and in E. (Leptempis) grisea the antennae are three-segmented, the scape is haired, the pedicel also always bears hairs or bristles, it is oval and elongated and equipped with a bisegmented style. The mouthparts are well developed, most frequently long and thin with a long labrum, a hypopharynx and a pair of maxilla, while the maxillary palps are short and only in the subgenus Euempis longer and haired.

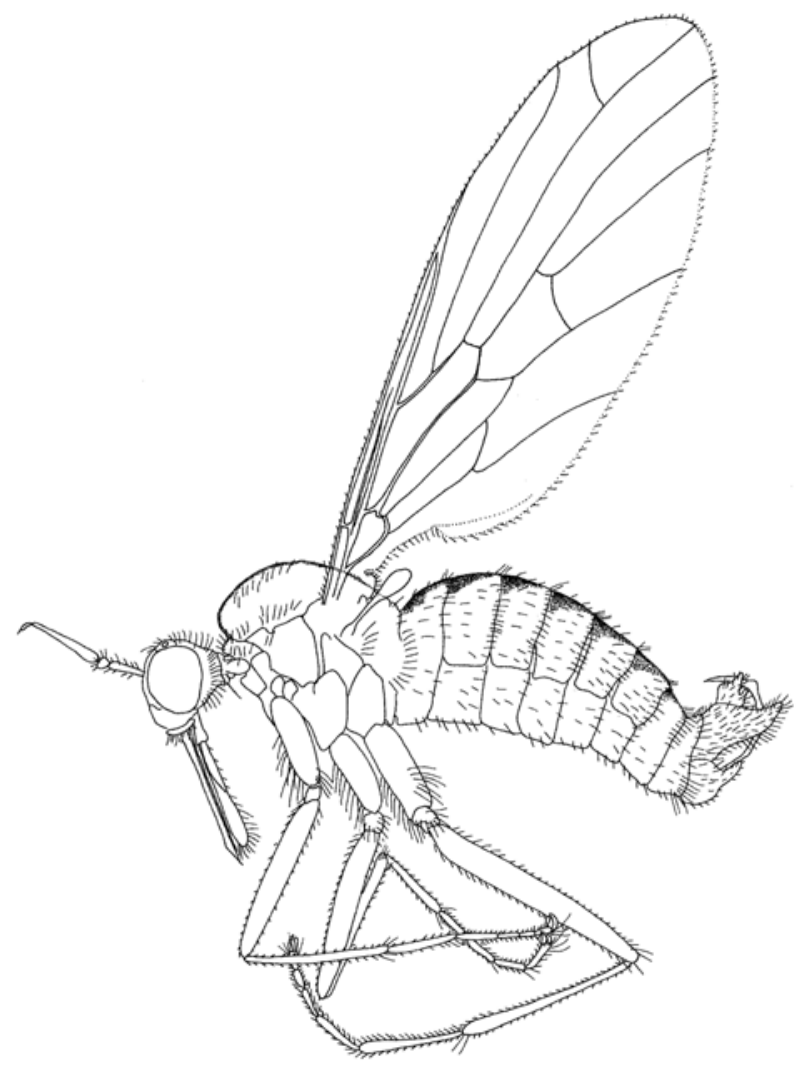

Fig. 1. Empis (Xanthempis) stercorea, female. 
The thorax is strong and thick, arch-like rounded in the dorsal part. Chaetotaxy of the thorax in the subgenera Euempis and Polyblepharis is not diverse, while in most species of the Empis s. str. it is decisively diverse and sometimes reduced, particularly in the posterior part of the thorax scutum. In the genus Xanthempis, acrostichal bristles are almost always absent, exept for females of $E$. lutea. Both acrostichal and dorsocentral bristles belong to the mesonotum. Metapleural chaetae are always present. The abdomen is soft, thinner than the thorax, cylindrical, in females slightly thicker.

Abdominal segmentation is usually well visible. Setae rows frequently occur on the tergites but in certain species they are reduced. In males, pregenital segments ( 7 and 8 ) do not compose a hypopygium. The tergite of the eighth segment is reduced to a small sclerite. In the genus Xanthempis the tergite and the sternite of the eighth segment form a single ring-shaped sclerite. The ninth and the rest of the following two segments composing the hypopygium are modified, covered by various thickenings and processes and are very strongly haired. In females the two last abdominal segments form the ovipositor (together with some other elements).

The wings are well-developed, transparent, milk-white or dimmed, in females occasionally very strongly. An oval wing spot (pterostigma) occurs in the upper part of the wing. In the subgenus Platyptera femele wings are very wide, "buttlerfly-like", decisively wider than in males. The veins approach the edge of the wing (in E. livida and Coptophlebia some veins do not reach the wing margin), while the discoidal cell occurring in the proximal part of the wing is elongated and rather narrow. A feature distinguishing the wing of the species of the genus Empis from the other genera of the Palaearctic Empidinae subfamily is the occurrence of a bifurcation of vein $\mathrm{R}_{4+5}$, whose branches form an obtuse angle. In contrast, in the genus Hilara the angle is acute, or close to acute, while in the genus Rhamphomyia there is no bifurcation at all and radial veins run directly to the edge of the wing. Within the subgenus Empis s. str. occurs a degree of sclerotisation of some veins and most veins are hardly visible, except for those located close to the upper edge of the wing - costa and subcosta. A detailed description of wing venation within the Empidinae, together with a discussion of venation variability and its evolutionary importance, was presented by Chvála (1983). This author indicated the same cases of reduction of $\mathrm{R}_{4}$ in Empis (Chvála 1994).

Male legs are short and slim. They are covered by very dense and long hair as well as by setae (Fig. 2). In females the legs are shorter, wider and flatter while the mid tibia, the mid femora and particularly the hind pair of legs are covered by characteristic "feather-like" setae (Fig. 3). In some males of the subgenus Empis s. str. and Coptophlebia first segments of fore and hind tarsi are widened, sometimes very strongly, resembling the genus Hilara in this respect. In the subgenera Aacrostichus and Pachymeria the femurs of the hind legs are thick, massive and covered by sharp chitonous thickenings and spikes. The legs of the second pair are shorter and thinner than the others; sometimes also long setae occur on them. Almost all dipterans of the genus Empis posses short and strong setae on the tibia of the hind legs or chitonous spikes forming the so-called "comb". Besides fulfilling functions related to mating behaviour, the setae, hair and chitonous thickenings on the legs are connected with receiving various stimuli. This surely serves as species-specific character or signal for a quick and correct recognition of different conspecific sexes (Chvála 1994).

The hypopygium is constructed according to a scheme common to Empididae and is composed of the epandrium, which is a transformed tergite of the ninth segment; the hypandrium originating from the sternite of the ninth segment is the base for the support of the copulatory organ (aedeagus) and well developed paired gonopods. An essential role in taxonomy is played by the gonopods, which usually have the form of a large flat sclerite which is very diverse dependent on the shape and size of a species; usually they are also strongly haired. The large, ovally rounded and haired hypandrium, is, particularly in its basic part, 
combined with the gonopods. The structure and evolution of the hypopygium in the whole Empididae family is described in detail by Bährmann (1960), Tréhen (1971), Ulrich (1972) and Chvála $(1983,1994)$. The formal terminology of the male terminalia elements is commonly used after Chvála (1994).
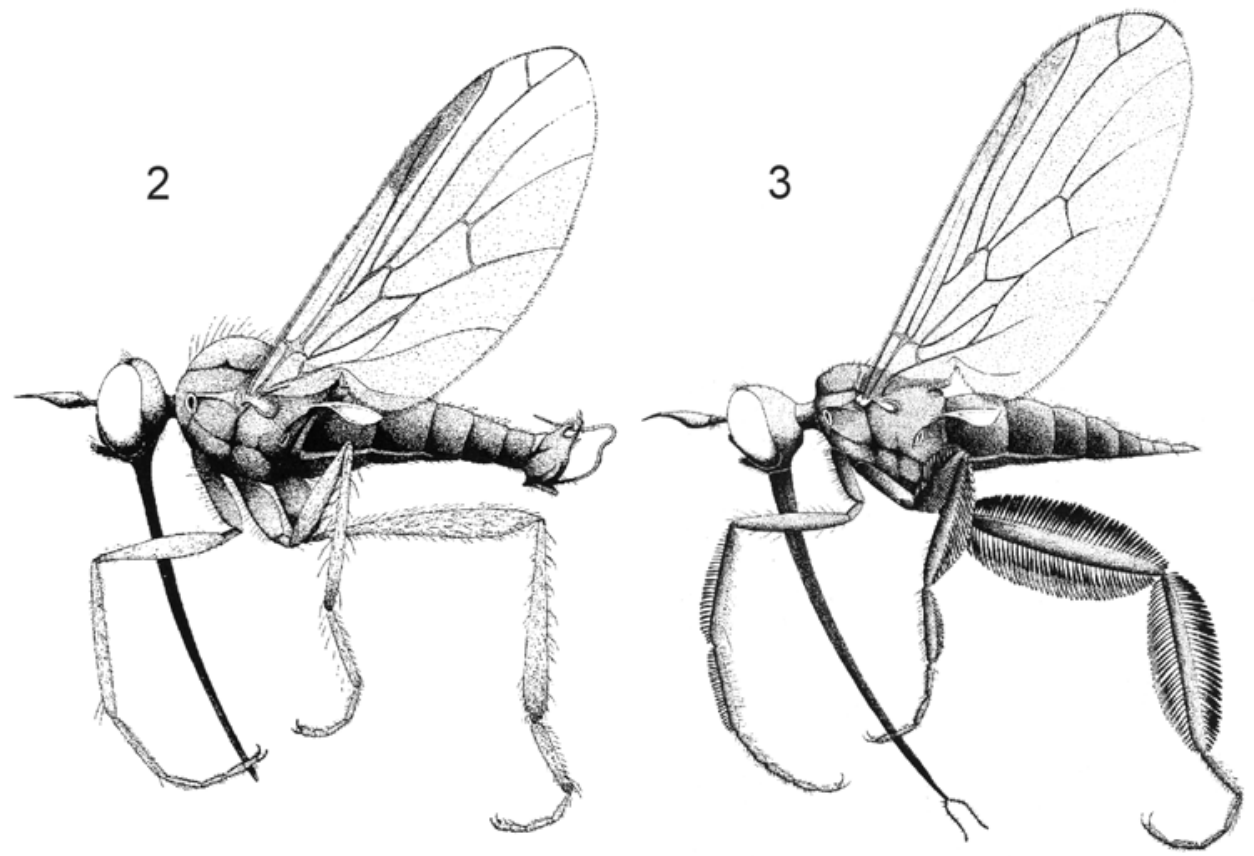

Figs 2-3. Empis (Empis) pennipes (according to Chvála 1994): 2 - male, 3 - female.

\section{MORPHOLOGY OF PREIMAGINAL STAGES}

Larvae are wormlike, fusiform in the frontal part and decisively larger and bulblikewidened in the posterior part. The epidermis is partially transparent, while the larva body is white or creamy colored. The head is of the hemicephalic type, with very small and weakly developed mouthparts forming the maxillary-mandibular complex (Fig. 4). Antennas are very short and thin, the lower labrum and the upper labrum are of similar length and shape and are in the form of a sharply terminated triangular plate, while reduced maxilla are connected with the basal part of the mandibles, whereas the maxillary palps are well visible. The body of the larva is composed of three thorax and eight thoracic segments. It is not haired. A pair of spiracles is well visible in the upper part of its last segment, while the anal orifice is located in its lower part. The larvae are metapneustic, the spiracles occurring on the thorax are rudimentary (they are actually spiracular discs with scar filaments) and they have lost connection with the respiratory system (Tréhen 1971). The pupa, as in all Brachycera, is of the free (pupa libera) type; light brownish with a clearly distinguished head part and well visible wing sheaths that also protect the leg nuclei. The abdomen of the pupa is composed of eight segments. There are numerous setae on its body, longer in the head and thorax part, and arranged in rows on the posterior edges of sternites and tergites. A pair of spiracles is well visible on the pupa thorax, while abdominal spiracles, which total seven pairs and are located on the abdomen sides, are very small and difficult to see. 


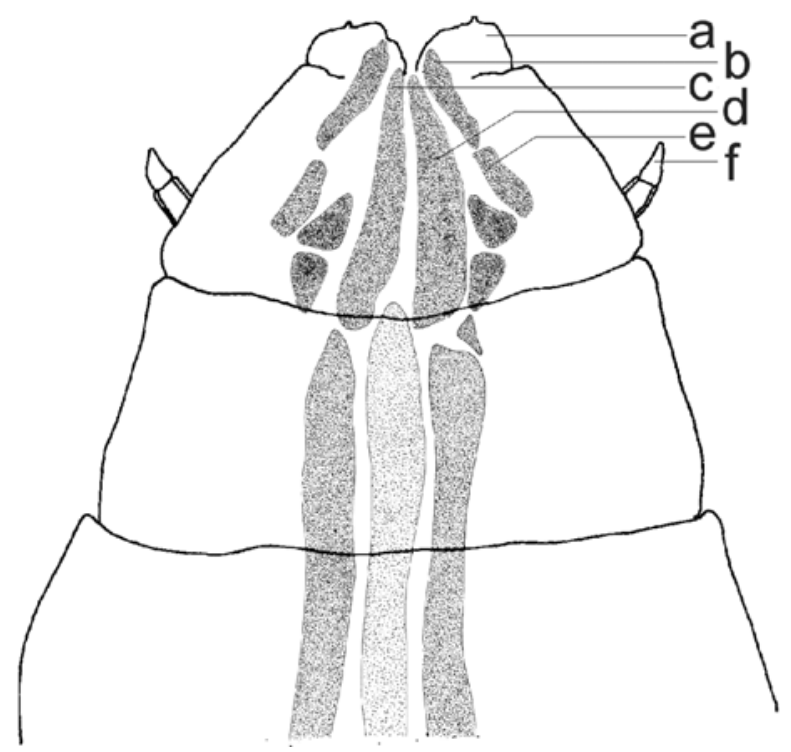

Fig. 4. Empis s. str. - frontal part of larval body: a - palpus maxillares, b - maxilla, c - labrum, d - labium, e mandibula, $\mathrm{f}$ - antenna.

\section{BIOLOGY OF THE ADULTS}

The biology of the genus Empis, similarly as of the whole Empididae family, is still little investigated. Almost all European dipterans of the genus Empis form flying swarms composed of various numbers of individuals, from several to several dozens. Forming of swarms precedes the mating flight and copulation. Swarms are initially formed by males, which are more abundant than females and which are waiting for the appearance of females. Only in exceptional cases, at the beginning or end of swarm forming, females may be more numerous than males, or swarms are formed by both, males and females (Chvála 1980). In the subgenera Polyplepharis, Kritempis and Anacrostichus the mating dance is performed by only several individuals dispersed over a relatively large area (Gruhl 1955). In contrast, in the case of Empis borealis, which appears in early spring, swarms are formed most frequently by females, while males, equipped with "mating gifts", appear later, approach the swarms and select females from them. Usually, a positive correlation between swarm size and number of visiting males, and even between swarm size and body sizes of females that form it, is recorded (Svensson \& Petersson 1992). However, Bayfield (1994) determined the presence of $E$. borealis swarms simultaneously composed of females and males and, besides, proved that air temperature exerts the highest impact on their formation (at a temperature below $13^{\circ} \mathrm{C}$ and at strong wind no swarm formation is observed). E. borealis appears on wing only in early spring, when willows are in blossom. During the mating dance the male gives the female the so-called "wedding present", called by certain authors a "nuptial gift". Such gifts are most frequently small body sized insects, among others Homoptera, Acalyptrata, Collembola, Chironomidae, Ephemeroptera, which complement the diet with highly calorific proteins; this being most relevant to females feeding on flower nectar (Chvála 1980, Svensson \& Petersson 1992, 1994, Preston-Mafham 1999). Mating behavior and also the character of the wedding gift, the method of its transfer and the flight preceding 
copulation differ from species to species (Chvála1994). In the species of E. trigramma, E. tesselata and E. opaca the female does not start to copulate without the reception of the nuptial gift and its obtaining seems to condition the development of ovaries. In the case of $E$. opaca males sometimes try to "cheat" females into accepting nutritionally worthless willow seeds, which are covered with dense hair, instead of small insects. As a rule, however, females reject such "false gifts". This is an example of an alternative tactic of mating behavior, which, however, is occasionally successful (Preston-Mafham 1999). The process of swarm formation and the mating rituals have developed during the course of evolution and have produced efficient mechanisms isolating sympatric species (Chvála 1990). Frequently, within the species Empis s. str. behaviour connected with transferring the "wedding gift" is of ritual character, while the gift itself is only a signal indicating the beginning of copulation. Probably, we have to do with a seigned increase in male size by the held victim, which is to persuade females to start copulating (Chvála 1980).

The dipterans of the genus Empis are predatory but numerous of them feed also or exclusively on flower nectar and pollen, which, according to certain authors, takes place very frequently and it is this form of foraging that is more frequent than predation (McAlpine et al. 1981, Chvála 1994). In other words, the role of dipterans of the genus Empis is important mostly not as predators but as insects fertilizing flowers (Hippa et al. 1981, Chvála 1994) and their development and taxonomic diversity is related mostly to the development of angiospermous plants (Waters 1989).

\section{BIOLOGY OF THE IMMATURE STAGES}

The biology of larvae and pupae is little known. The larvae, which in most species are the overwintering stage, live both in forest and in meadow soil, and also in various kinds of moist and bog terrain, close to water reservoirs, moors and, as it is the case with $E$. trigramma, in manure (Collin 1961, Tréhen 1971, Chvála 1994). Chvála (1994) stated that the larvae of numerous genus Empis species develop close to willows. Similarly as it is the case with other Empididae, the larvae of Empis are predatory. They hunt small body size insects, particularly long-antenna dipterans (Nematocera) (Collin 1961, Van der Goot 1989, Chvála \& Vrtiskova-Bouskova 1989, Wehlitz 1992, Bayfield 1994). In cultures, they eagerly consume genus Drosophila larvae (McAlpine et al. 1981). Data from literature are confirmed in the construction of the mouthparts of the larvae and also in the present author's observations carried out during rearing preimaginal stages. The pupa stage lasts short, usually about 10 days, and before leaving the exuvium as an imago the pupa moves to the surface earth layer.

\section{MATERIALS AND METHODS}

The adults of the genus Empis were collected mostly in the 80s of the 20th century using the entomological net in the area of whole Poland. Particularly waterside shrubs and meadows, especially in mountainous and submountainous terrain and in the area of the Roztocze, Mazovia, Suwałki and Western Pomerania Regions were intensively studied. Part of the material collected by the 'yellow pans' method was obtained by researchers of the Museum and Institute of Zoology Polish Academy of Sciences in Warsaw (MZW), mainly in the Białowieża Primeval Forest and in the area of Warsaw and its vicinities, for which I extend great thanks to them. The whole material, preserved in $70 \%$ alcohol, is deposited in the collection of the Department of Invertebrate Zoology and Hydrobiology of the University of Łódź. 


\section{LIST OF THE SPECIES}

47 species of the genus Empis were recorded in Poland. These dipterans occur from April to October, but most number of the recorded species is observed in the period May-June (Table 1).

Table 1. The occurrence of species of the genus Empis in Poland.

\begin{tabular}{|c|c|c|c|c|c|c|c|c|c|c|c|c|c|}
\hline \multirow{2}{*}{ No. } & \multirow{2}{*}{ Species } & \multicolumn{12}{|c|}{ Months } \\
\hline & & $\mathrm{I}$ & II & III & IV & $\mathrm{V}$ & VI & VII & VIII & IX & $\mathrm{X}$ & $\mathrm{XI}$ & XII \\
\hline 1 & Empis tesselata Fabricius, 1794 & & & & & $\mathrm{x}$ & $\mathrm{x}$ & $\mathrm{x}$ & & & & & \\
\hline 2 & Empis picipes Meigen, 1804 & & & & & $\mathrm{x}$ & & & & & & & \\
\hline 3 & Empis opaca Meigen, 1804 & & & & $\mathrm{x}$ & $\mathrm{x}$ & $\mathrm{x}$ & & & & & & \\
\hline 4 & Empis livida Linnaeus, 1758 & & & & & & $\mathrm{x}$ & $\mathrm{x}$ & $\mathrm{x}$ & & & & \\
\hline 5 & Empis nitida Meigen, 1804 & & & & & $\mathrm{x}$ & $\mathrm{x}$ & & & & & & \\
\hline 6 & Empis bistortae Meigen, 1822 & & & & & & $\mathrm{x}$ & $\mathrm{x}$ & $\mathrm{x}$ & & & & \\
\hline 7 & Empis borealis Linnaeus, 1758 & & & & $\mathrm{x}$ & $\mathrm{x}$ & & & & & & & \\
\hline 8 & Empis flavitarsis von Roser 1840 & & & & & & $\mathrm{x}$ & & & & & & \\
\hline 9 & Empis nigricans Meigen, 1804 & & & & & $\mathrm{x}$ & $\mathrm{x}$ & $\mathrm{x}$ & & & & & \\
\hline 10 & Empis mesogramma Loew, 1867 & & & & & & $\mathrm{x}$ & & & & & & \\
\hline 11 & Empis grisea Fallen, 1816 & & & & & & $\mathrm{x}$ & $\mathrm{x}$ & $\mathrm{x}$ & & & & \\
\hline 12 & Empis pennipes Linnaeus, 1758 & & & & $\mathrm{x}$ & $\mathrm{x}$ & $\mathrm{x}$ & & & & & & \\
\hline 13 & Empis cincinnatula Loew, 1867 & & & & & & $\mathrm{x}$ & $\mathrm{x}$ & & & & & \\
\hline 14 & Empis acinerea Chvála, 1985 & & & & & $\mathrm{x}$ & & & & & & & \\
\hline 15 & Empis genualis Strobl, 1893 & & & & & & & & $\mathrm{x}$ & & & & \\
\hline 16 & Empis gymnopoda Bezzi, 1908 & & & & & $\mathrm{x}$ & & & & & & & \\
\hline 17 & Empis planetica Collin, 1927 & & & & & $\mathrm{x}$ & $\mathrm{x}$ & & & & & & \\
\hline 18 & Empis melanotricha Loew, 1873 & & & & & $\mathrm{x}$ & & & & & & & \\
\hline 19 & Empis woodi Collin, 1927 & & & & & $\mathrm{x}$ & & & & & & & \\
\hline 20 & Empis bicuspidate Collin, 1927 & & & & & $\mathrm{x}$ & $\mathrm{x}$ & & & & & & \\
\hline 21 & Empis nuntia Meigen, 1838 & & & & & $\mathrm{x}$ & & & & & & & \\
\hline 22 & Empis chioptera Meigen, 1838 & & & & & $\mathrm{x}$ & $\mathrm{x}$ & & & & & & \\
\hline 23 & Empis beckeriana Engel, 1946 & & & & & $\mathrm{x}$ & & $\mathrm{x}$ & & & & & \\
\hline 24 & Empis prodromus Loew, 1867 & & & & & $\mathrm{x}$ & & $\mathrm{x}$ & & & & & \\
\hline 25 & Empis dasyprocta Loew, 1867 & & & & & $\mathrm{x}$ & & & & & & & \\
\hline 26 & Empis caudatula Loew, 1867 & & & & & $\mathrm{x}$ & $\mathrm{x}$ & $\mathrm{x}$ & $\mathrm{x}$ & & & & \\
\hline 27 & Empis aestiva Loew, 1867 & & & & & & & $\mathrm{x}$ & $\mathrm{x}$ & $\mathrm{x}$ & & & \\
\hline 28 & Empis alpicola Strobl, 1893 & & & & & & $\mathrm{x}$ & & & & & & \\
\hline 29 & Empis anfractuosa Mik, 1884 & & & & & $\mathrm{x}$ & & & & & & & \\
\hline 30 & Empis apfelbecki Strobl, 1898 & & & & & $\mathrm{x}$ & $\mathrm{x}$ & & & & & & \\
\hline 31 & Empis nigripes Fabricius, 1794 & & & & & $\mathrm{x}$ & $\mathrm{x}$ & & & & & & \\
\hline 32 & Empis maerens Loew, 1867 & & & & & & & $\mathrm{x}$ & & & & & \\
\hline 33 & Empis filata Loew, 1873 & & & & $\mathrm{x}$ & $\mathrm{x}$ & $\mathrm{x}$ & & & & & & \\
\hline 34 & Empis hyalipennis Fallen, 1816 & & & & & & & $\mathrm{x}$ & & & & & \\
\hline 35 & Empis impennis Strobl, 1902 & & & & & & $\mathrm{x}$ & $\mathrm{x}$ & & & & & \\
\hline 36 & Empis albinervis Meigen, 1822 & & & & & & $\mathrm{x}$ & & & & & & \\
\hline 37 & Empis vitripennis Meigen, 1822 & & & & & & & & $\mathrm{x}$ & $\mathrm{x}$ & $\mathrm{x}$ & & \\
\hline 38 & Empis pilimana Loew, 1869 & & & & & & & & & $\mathrm{x}$ & & & \\
\hline 39 & Empis lutea Meigen, 1804 & & & & & & & & $\mathrm{x}$ & & & & \\
\hline 40 & Empis concolor Verall, 1872 & & & & & & & $\mathrm{x}$ & & & & & \\
\hline 41 & Empis stercorea Linnaeus, 1761 & & & & & $\mathrm{x}$ & $\mathrm{x}$ & & & & & & \\
\hline 42 & Empis aemula Loew, 1873 & & & & & $\mathrm{x}$ & $\mathrm{x}$ & $\mathrm{x}$ & & & & & \\
\hline 43 & Empis univittata Loew, 1867 & & & & & & $\mathrm{x}$ & $\mathrm{x}$ & & & & & \\
\hline 44 & Empis aequalis Loew, 1867 & & & & & & $\mathrm{x}$ & & & & & & \\
\hline 45 & Empis trigramma Wiedemann, 1822 & & & & & $\mathrm{x}$ & $\mathrm{x}$ & & & & & & \\
\hline 46 & Empis punctata Meigen, 1804 & & & & & & $\mathrm{x}$ & & & & & & \\
\hline 47 & Empis digramma Meigen, 1835 & & & & & & $\mathrm{x}$ & & & & & & \\
\hline & Number of species & 0 & 0 & 0 & 4 & 26 & 28 & 16 & 8 & 3 & 1 & 0 & 0 \\
\hline
\end{tabular}




\section{Empis (Euempis) tesselata Fabricius, 1794}

(Figs 5-6)

A rather widely distributed species in the Palearctic; from southern Scandinavia, through whole Europe, including Portugal and countries located on the Mediterranean (unrecorded in the Azores) and northern Africa up to Japan (Collin 1961, Hobby \& Smith 1961, Chvála \& Wagner 1989, Chvála 1994, 1998, Barták \& Roháček 1999, Preston-Mafham 1999).

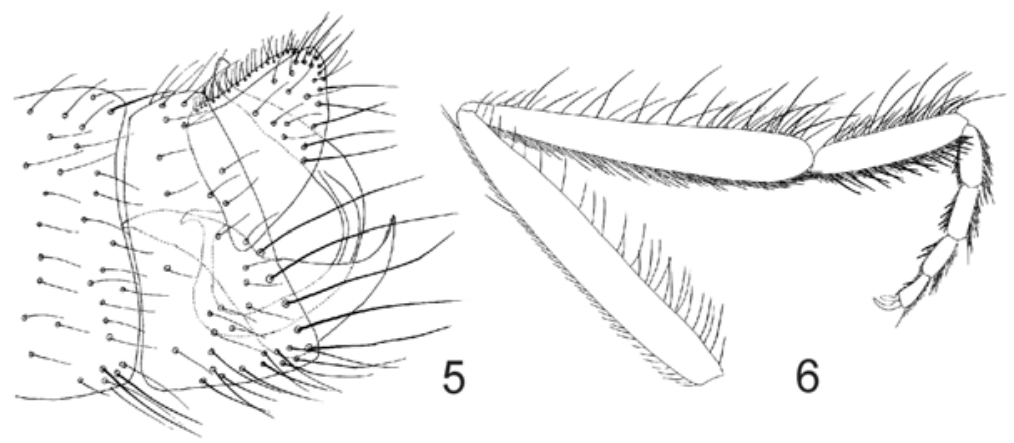

Figs 5-6. Empis (Empis) tesselata; 5 - hypopygium, 6 - hind leg.

In Poland reported in old faunal inventories (Palaczyk 1991), recorded also in the Bieszczady Mountains (Klasa et al. 2000), the Białowieża Primeval Forest (Palaczyk 2001) and the massive of the Babia Mount (Palaczyk \& Klasa 2003).

Between May and July it was recorded in the Świętokrzyskie Mts, in the Roztocze and Bieszczady Mts, in the Pieniny and Tatra Mts; it does not occur higher than $1200 \mathrm{~m}$ a.s.1.; it also occurs on the Baltic coast, in the vicinities of the towns of Torun, Łódź and in the area of the Kampinoski National Park.

\section{Empis (Euempis) picipes Meigen, 1804}

(Figs 7-9)
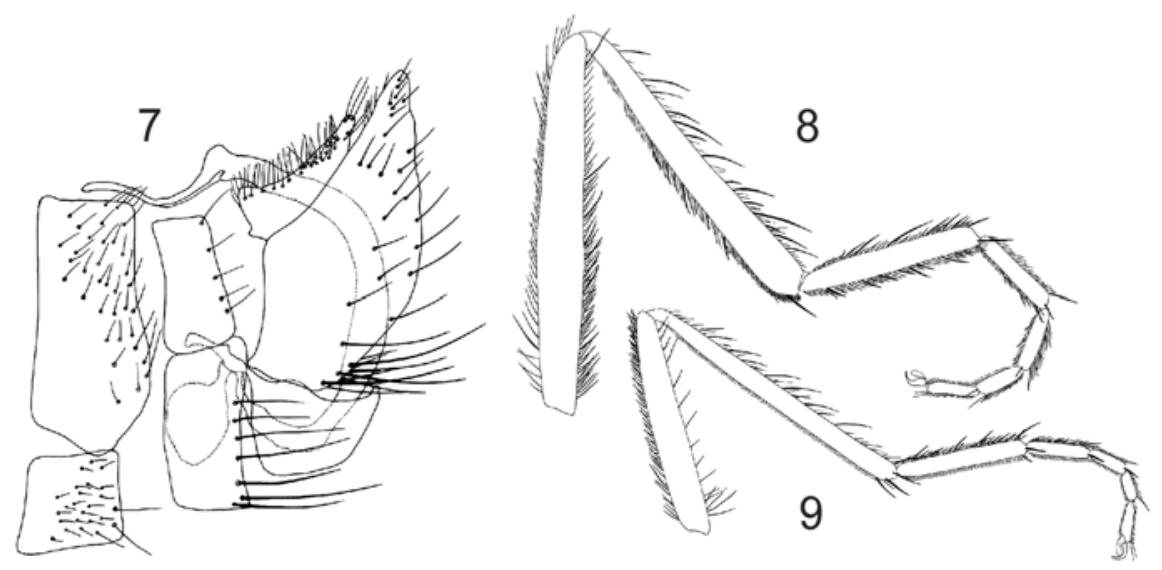

Figs 7-9. Empis (Euempis) picipes; 7 - hypopygium, 8 - hind leg, 9 - middle leg. 
A rather widely distributed species in Europe, from the British Isles and south Scandinavia to central Europe, northern Italy and Greece; everywhere uncommon (Engel 1938-1954, Collin 1961, Chvála \& Wagner 1989, Chvála 1994, Pesarini et al. 1995, Plant 2003). In Poland recorded only by Palaczyk (1991).

One male was captured 30 May 1995 in the botanic garden in Łódź (leg. K. Kowalczyk).

\section{Empis (Polyblepharis) opaca Meigen, 1804}

(Figs 10-11)

Occurs in the colder part of Europe. Reported on the British Isles, in Scandinavia, northern and central Russia, Holland, Belgium, France, Germany, the Czech Republic and Slovakia, Austria, northern Italy and Switzerland (Engel 1938-1956, Collin 1961, Hobby \& Smith 1962, Chvála \& Wagner 1989, van der Goot 1989, Chvála 1994, 1998, Meyer \& Filipinski 1998, Barták \& Roháček 1999, Preston-Mafham 1999, Grootaert et al. 2001).

In Poland it was reported in old faunal inventories (Palaczyk 1991), recorded also in the Bieszczady Region (Klasa et al. 2000) and in the massive of the Babia Mount, where it does not exceed the height of $700 \mathrm{~m}$ a.s.l. (Palaczyk \& Klasa 2003).

It is a spring species, encountered between April and early June in the Świętokrzyskie Mts, in the Roztocze Region, in the vicinities of the towns of Torun and Łódź, in the Masovian and Western Pomeranian Regions.

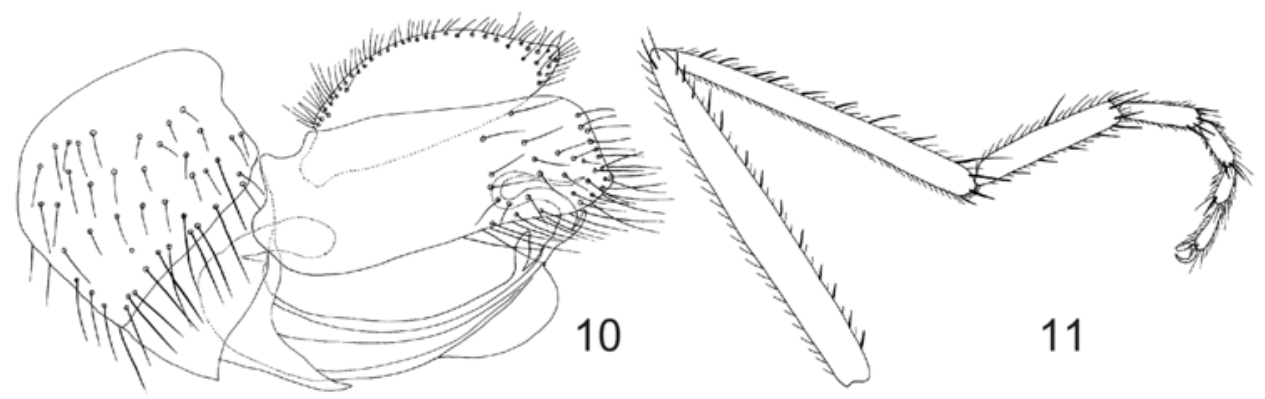

Figs 10-11. Empis (Polyblepharis) opaca; 10 - hypopygium, 11 - hind leg.

\section{Empis (Kritempis) livida Linnaeus, 1758}

(Figs 12-13)

A rather widely distributed species in Europe, from the British Isles, Scandinavia, northern and central Russia to central and western Europe, Switzerland and northern Italy (Engel 19381956, Collin 1961, Wéber 1981, Ceianu 1992, Wehlitz 1992, Chvála \& Wagner 1989, Chvála 1994, 1997, 1998, Chvála, et al. 1998, Meyer \& Filipinski 1998, Barták \& Roháček 1999, Chvála \& Barták 2000, Grootaert et al. 2001).

In Poland, it was reported in old faunistic inventories (Palaczyk 1991), recorded in the Bieszczady Mts, where it occurs up to $1000 \mathrm{~m}$ a.s.1. (Klasa et al. 2000), the Białowieża Primeval Forest (Palaczyk 2001) and the massive of the Babia Mount (Palaczyk \& Klasa 2003).

It was recorded between June and late August in the Masurian Lakeland in the vicinity of the town of Kętrzyn, in the Suwałki-Augustów Lakeland, in the brackish water bodies of the Kujawy Region near the town of Ciechocinek, in the vicinity of Warsaw and in Warsaw itself, in the Łódź Upland and in the towns of Łódź, Cracow, Busko (leg. W. Krzemiński), in the Beskid Niski Mts, in the Pieniny Mts and at the town of Zakopane. 


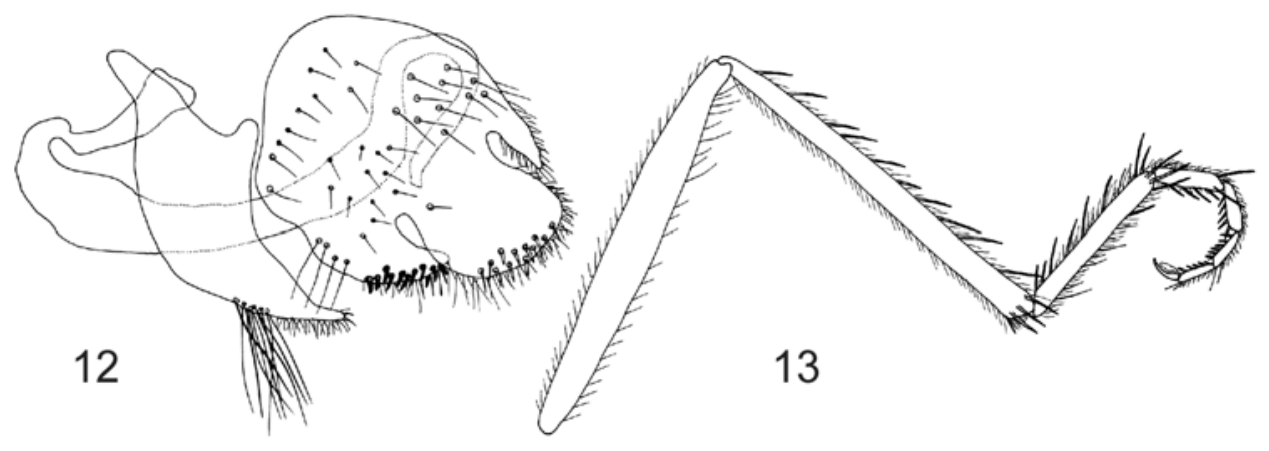

Figs 12-13. Empis (Kritempis) livida; 12 - hypopygium, 13 - hind leg.

\section{Empis (Anacrostichus) nitida Meigen, 1804}

(Figs 14-15)

It occurs on the British Isles, in Scandinavia, Karelia, Holland, Germany, the Czech Republic, Austria, Switzerland, France and northern Italy (Engel 1938-1956, Collin, 1961, Chvála \& Wagner 1989, van der Goot 1989, Chvála 1994, 1997, Pesarini et al. 1995, Plant 2003).

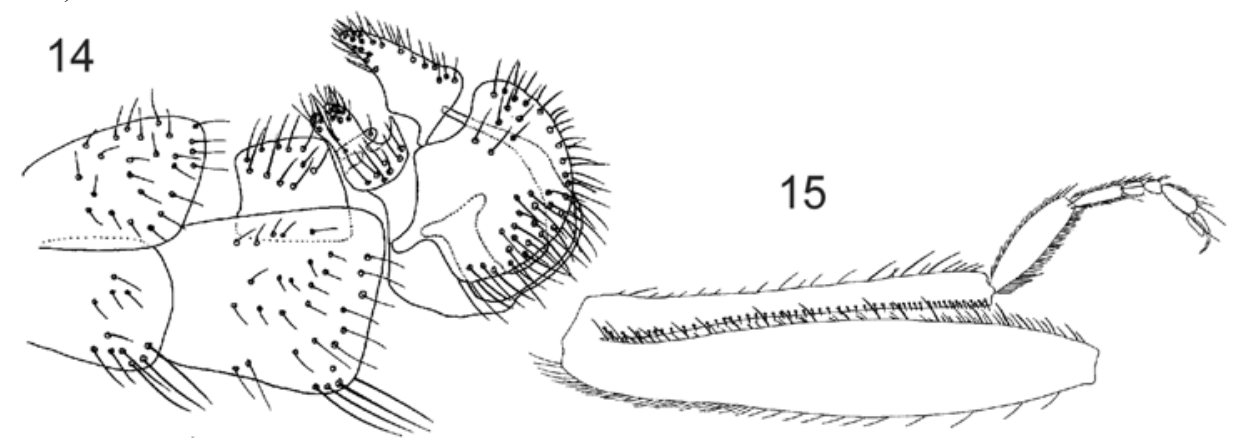

Figs 14-15. Empis (Anacrostichus) nitida; 14 - hypopygium, 15 - hind leg.

In Poland, it was reported in old faunal inventories (Palaczyk 1991) and in the massive of the Babia Mount, where it occurs at $850 \mathrm{~m}$ a.s.1. (Palaczyk \& Klasa 2003).

It is a spring species, recorded in May and in June in the Roztocze, in the Świętokrzyskie Mts, the Kampinoski National Park and at the village of Radziejowice near Warsaw, where it was captured in yellow pans.

\section{Empis (Anacrostichus) bistortae Meigen, 1822}

(Fig. 16)

It is distributed between the Pyrenean Peninsula through France, Belgium, Holland, Germany, the Czech Republic and Slovakia up to Ukraine (Engel 1938-1956, Chvála \& Wagner 1989). Chvála (1994) claims that its occurrence is also possible in southern Scandinavia.

In Poland, it was reported in old faunal inventories (Palaczyk 1991) and also in the massive of the Babia Mount, where it occurs up to $1700 \mathrm{~m}$ a.s.l. (Palaczyk \& Klasa 2003) and in the Bieszczady Mts, where it was recorded in the highest parts, i.e. at $1400 \mathrm{~m}$ a.s.l. (Klasa et al. 2000). 


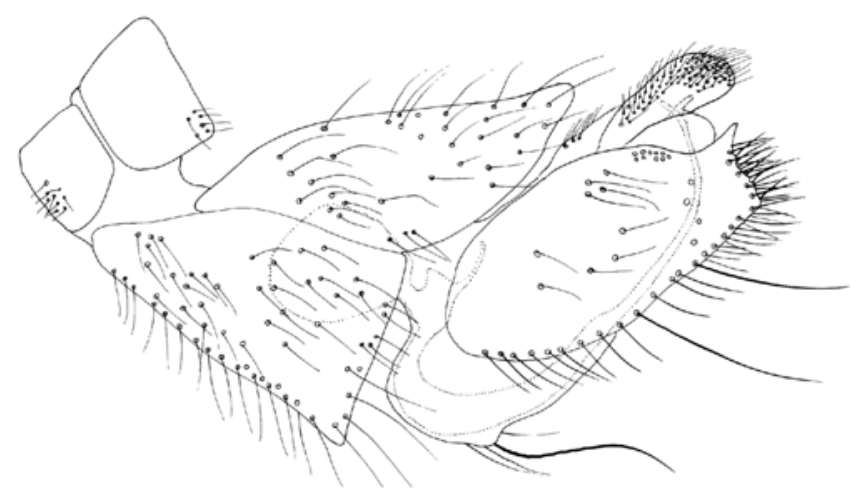

Fig. 16. Empis (Anacrostichus) bistortae, hypopygium.

It is a mountainous species, recorded between June and late August in the Kłodzka Dale, Tatra Mts, both at Zakopane and in high mountains, even above $1600 \mathrm{~m}$ a.s.1., in the Gorce Mts at heights of about $1000 \mathrm{~m}$ a.s.l. and in the Bieszczady Mts in shrubs at a spring at the town of Tarnica, and also in the mid-forest meadows situated on the southern slopes.

\section{Empis (Platyptera) borealis Linnaeus, 1758}

(Figs 17-18)

A species typical of northern Scandinavia but widespread in whole northern, western, middle and eastern Europe, and also in western Siberia (Engel 1938-1956, Collin 1961, Chvála \& Wagner 1989, van der Goot 1989, Svensson et al. 1989, Ceianu 1992, Svensson \& Petersson 1992, 1994, Wehlitz 1992, Bayfield 1994, Chvála 1994, Barták \& Roháček 1999, Grootaert et al. 2001, Plant 2003).
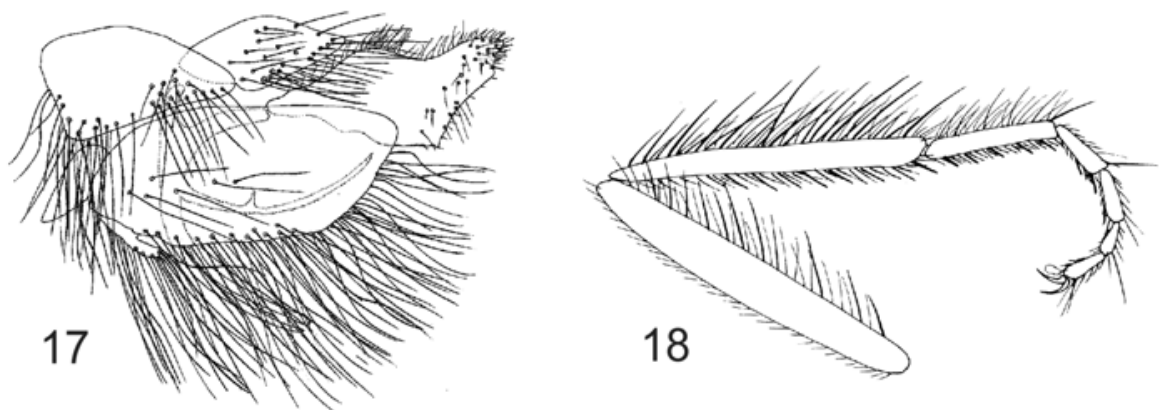

Figs 17-18. Empis (Platyptera) borealis; 17 - hypopygium, 18 - middle leg.

In Poland, it was reported in old faunal inventories (Palaczyk 1991) and also in the Białowieża Primeval Forest (Palaczyk 2001) and in the massive of the Babia Mount, where it occurs up to $1650 \mathrm{~m}$ a.s.1. (Palaczyk \& Klasa 2003).

It is a spring species, one of the earliest appearing species of the whole family Empididae. It occurs in April and May, flying in small swarms over the surface and in the vicinity of stagnant water reservoirs, various pools, river and stream meanders and even water collected in 
ruts of mid-forest roads, etc. It is recorded in the Roztocze Region, the Świętokrzyskie Mts, and the Tatra Mts at heights of $1600 \mathrm{~m}$ a.s.l.

\section{Empis (Leptempis) flavitarsis von Roser 1840}

(Fig. 19)

It is a species reported in Germany, the Czech Republic and Slovakia, Switzerland, Italy and former Yugoslavia (Engel 1938-1956, Chvála \& Wagner 1989, Pesarini et al. 1995, Chvála 1998).

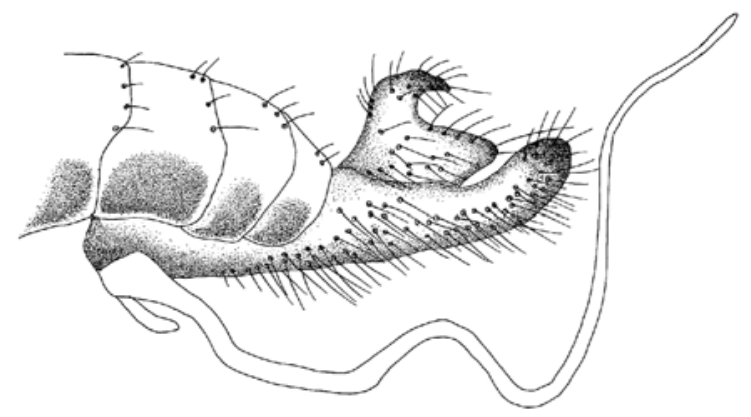

Fig. 19. Empis (Leptempis) flavitarsis, hypopygium (according to Engel 1938-1956).

It is new for Poland. One male was found at the height of $800 \mathrm{~m}$ a.s.1. in a meadow lying by the side of the Prowcza Stream in the Bieszczady Mts on 26 June 1986.

\section{Empis (Leptempis) nigricans Meigen, 1804}

(Figs 20-21)

It is a species noted from Holland, Germany, Austria, the Czech Republic, Hungary, Slovenia, northern Italy and Romania (Engel 1938-1956, Chvála \& Wagner 1989, Ceianu 1992, Pesarini et al. 1995, Chvála 1998, Barták \& Roháček 1999, Chvála \& Barták 2000).

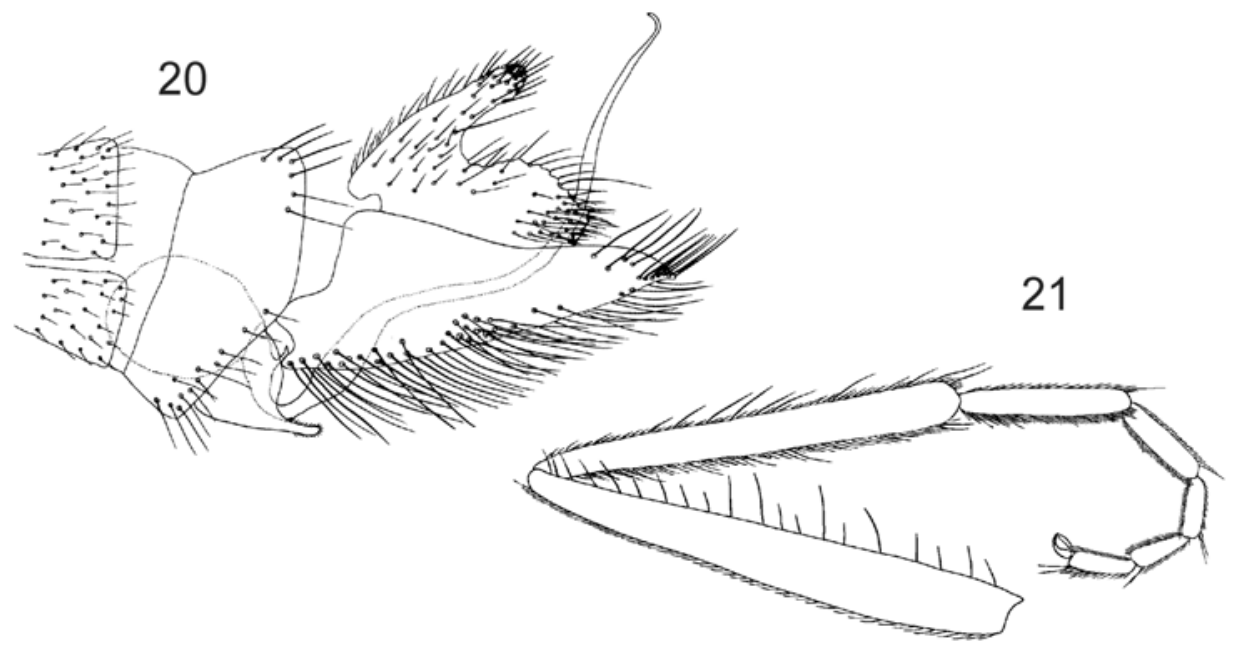

Figs 20-21. Empis (Leptempis) nigricans; 20 - hypopygium, 21 - middle leg. 
In Poland, it was reported in old faunal inventories (Palaczyk 1991) and also in the massive of the Babia Mount, where it occurs at a height of $720 \mathrm{~m}$ a.s.l. (Palaczyk \& Klasa 2003).

It occurs from May to July. It was recorded in the Pieniny Mts, the Roztocze Region, the Świętokrzyskie Mts and on meadows in the village Jeżewo in the vicinity of Łódź.

\section{Empis (Leptempis) mesogramma Loew, 1867}

(Figs 22-24)

It is a species reported from the Czech Republic and Slovakia, Austria (Carinthia), Italy and former Yugoslavia (Engel 1938-1956, Chvála \& Wagner 1989, Pesarini et al. 1995, Chvála 1997, 1998).

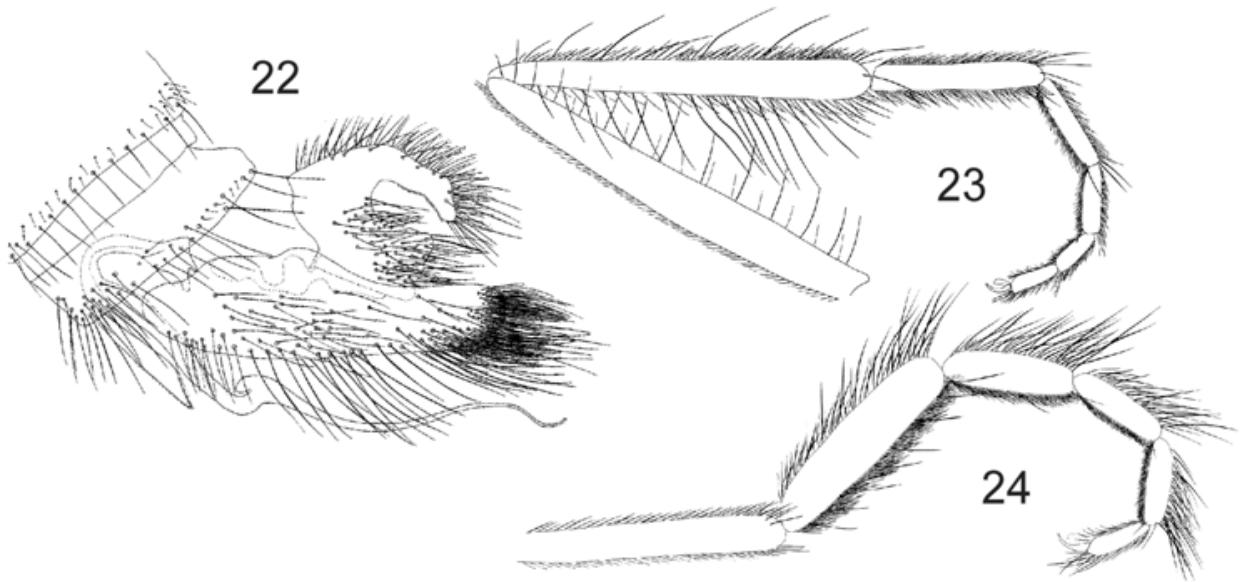

Figs 22-24. Empis (Leptempis) mesogramma; 22 - hypopygium, 23 - fore leg, 24 - hind leg.

In Poland, it was reported in old faunal inventories (Palaczyk 1991); also recorded in the Bieszczady Mts at a height of $900 \mathrm{~m}$ a.s.l. (Klasa et al. 2000) and in the massive of the Babia Mount in the Zawoja Range at a height of 700-800 m a.s.l. (Palaczyk \& Klasa 2003).

It occurs in the second half of June at Zakopane; also in the Gorce Mts at the height of about 900 m a.s.l. and in the Bieszczady Region and the Borecka Forest.

\section{Empis (Leptempis) grisea Fallen, 1816}

(Figs 25-26)
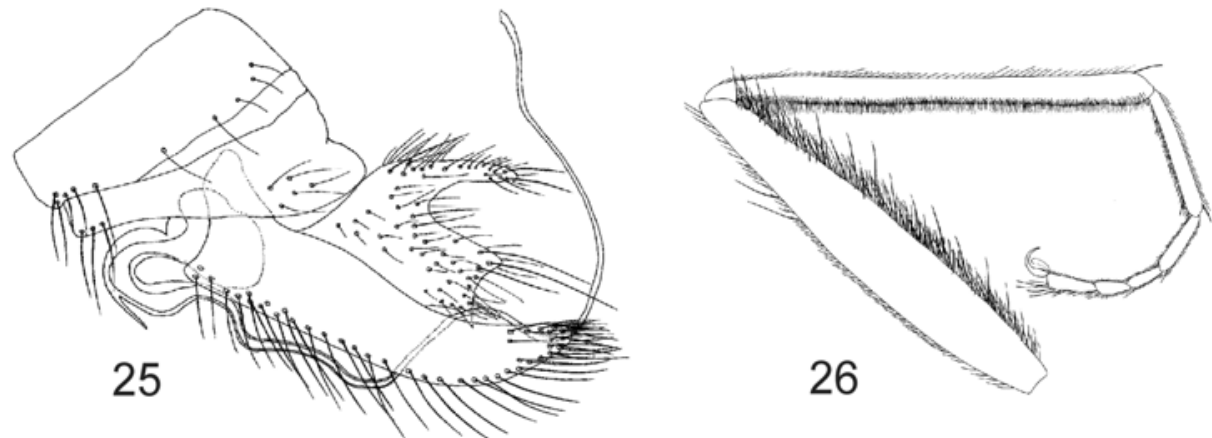

Figs 25-26. Empis (Leptempis) grisea; 25 - hypopygium, 26 - hind leg. 
It is a species widely distributed in Europe; from the British Isles, Ireland, across southern Scandinavia, western Europe, central Europe up to Switzerland, Austria, northern Italy, Romania and former Yugoslavia (Engel 1938-1956, Collin 1961, Chvála 1994, 1997, Barták \& Roháček 1999, Plant 2003).

In Poland, it was reported in old faunal inventories (Palaczek 1991), in the massive of the Babia Mount (Palaczyk \& Klasa 2003) and in the Bieszczady Mts, at the height of 650-850 m a.s.l. (Klasa, et al. 2000).

In the vicinity of Zakopane and in the Bieszczady Region it occurs from June to August.

\section{Empis (Empis) pennipes Linnaeus, 1758}

(Figs 27-30)

A species typical for colder regions of Europe. Reported from the British Isles, Belgium, Scandinavia, Karelia, northern and central Russia, Germany, the Czech Republic, Slovakia, Hungary, Romania; the southern geographical limit is in northern France, Italy, and former Yugoslavia (Engel 1938-1956, Collin 1961, Wéber 1981, Chvála \& Wagner 1989, Ceianu 1992, Pesarini et al. 1995, Chvála 1994, 1998, Chvála \& Barták 2000, Grootaert et al. 2001, Plant 2003).

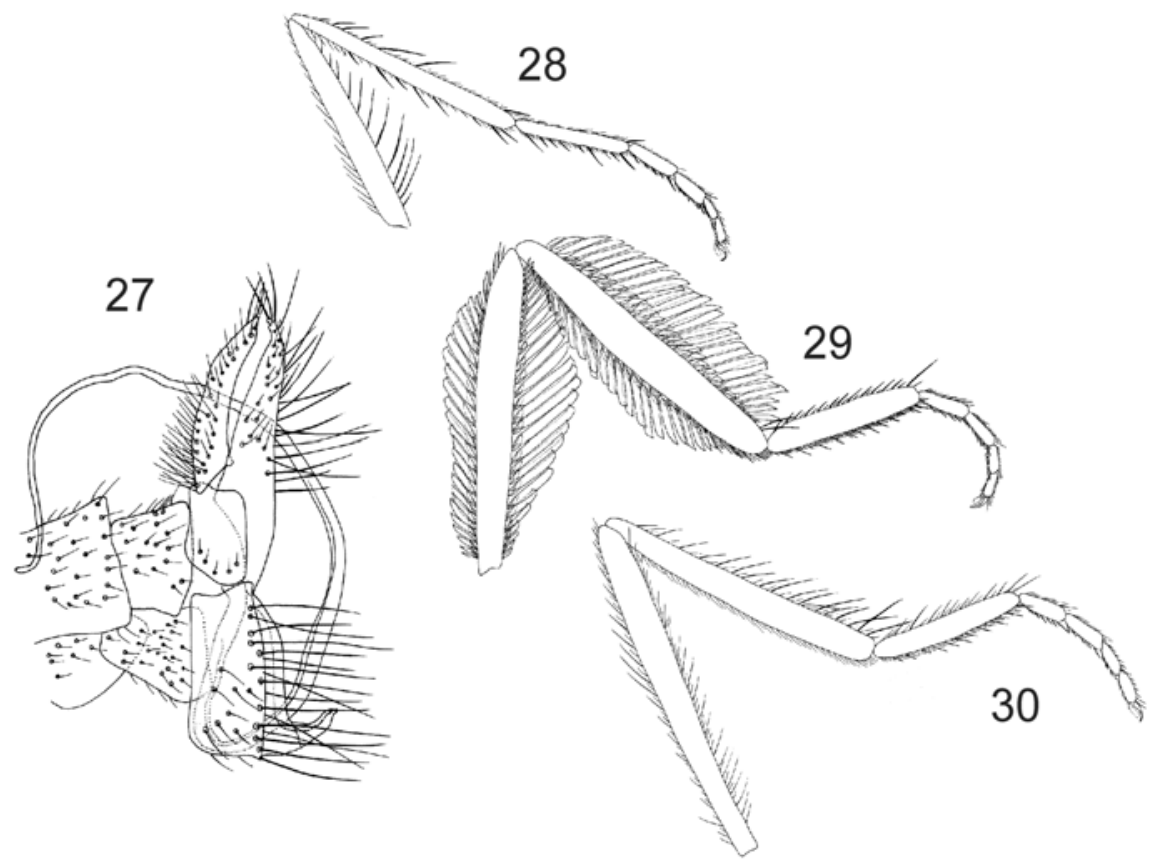

Figs 27-30. Empis (Empis) pennipes; 27 - hypopygium, 28 - middle leg, 29 - female hind leg, 30 - male hind leg.

In Poland, it was reported in old faunal inventories (Palaczyk 1991), in the Bieszczady Mts, at the height 500 m. a.s.1., in the Białowieża Primeval Forest (Palaczyk 2001) and the massive of the Babia Mount (Palaczyk \& Klasa 2003).

It is a spring species, occuring from April to June, reported in the Świętokrzyskie Mts, the Roztocze Region, the Bieszczady Mts, the Niepołomicka Forest and in the botanic garden in Łódź (leg. K. Kowalczyk). 


\section{Empis (Empis) cincinnatula Loew, 1867}

(Figs 31-33)

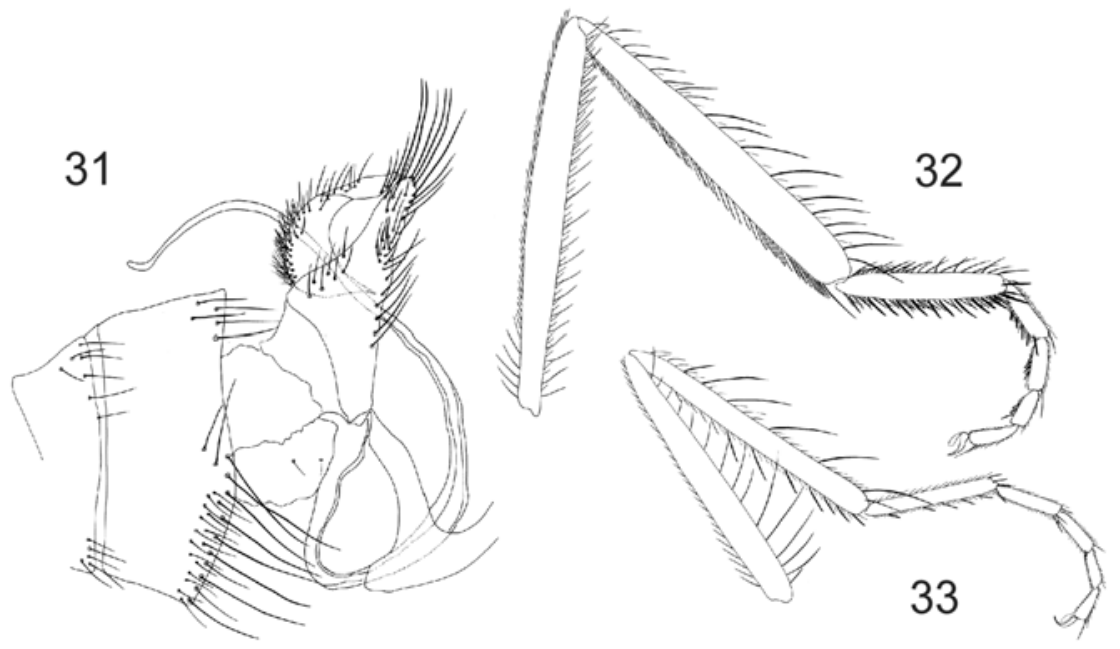

Figs 31. Empis (Empis) cincinnatula; 31 - hypopygium, 32 - hind leg, 33 - middle leg.

It is reported in Austria and the northern regions of former Yugoslavia (Engel 1938-1956, Syrovátka \& Chvála 1986, Chvála \& Wagner 1989, Syrovátka 1991).

It is new for Poland. It was collected at the village of Radziejowice near Warsaw by the 'yellow pans' method; it was obtained by the researchers of MZW in June 1984 in the forest at Radziejowice near Warsaw and also in the Tatra Mts in the bushes growing on the banks of the affluent of the Białka River at the height of $460 \mathrm{~m}$ a.s.l. The occurrence in Poland represents a northern border of its distribution in Europe.

\section{Empis (Empis) acinerea Chvála, 1985}

(Figs 34-36)

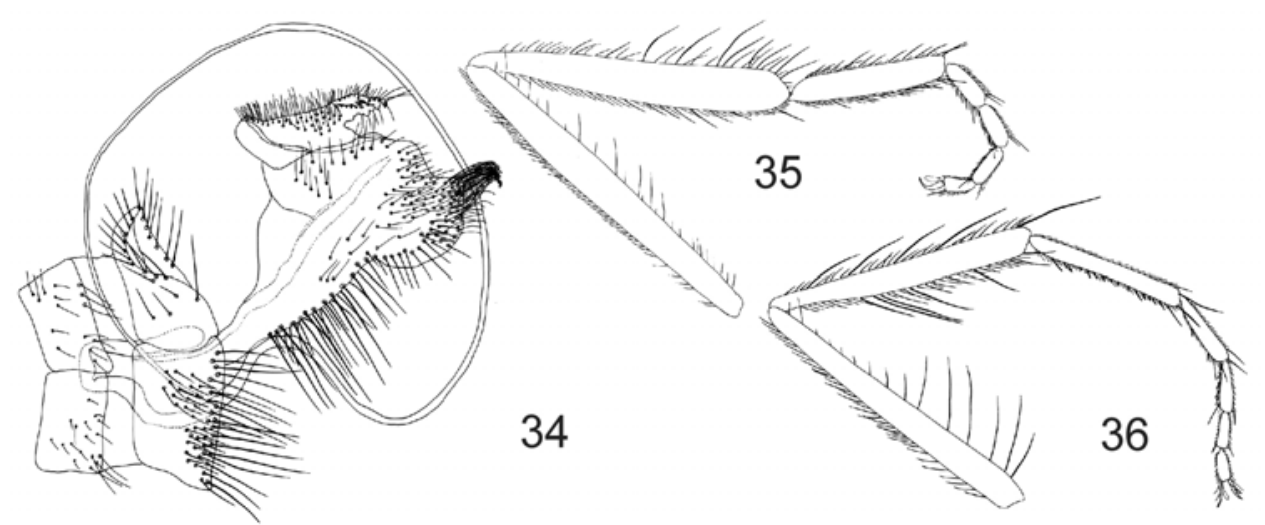

Figs 34-36. Empis (Empis) acinerea; 34 - hypopygium, 35 - hind leg, 36 - middle leg. 
It is reported in Scandinavia and the Baltic States, Holland, Belgium, Germany and the Czech Republic (Chvála \& Wagner 1989, van der Goot 1989, Chvála 1994, 1997a, 1997b, 1998, Chvála \& Barták 2000, Grootaert et al. 2004).

In Poland, it was noted in old faunal inventories (Palaczyk 1991).

Two males captured in yellow pans from tree tops in the oak-hornbeam wood of the Białowieża Primeval Forest at the town of Topiło on 8 May 1994 (leg. W. Mikołajczyk).

\section{Empis (Empis) genualis Strobl, 1893}

(Figs 37-40)

It is a species characteristic for the Mediterranean Region. It was noted in Italy, Spain, Corsica, Croatia, Macedonia and Greece, and also in Holland, Belgium, the Czech Republic and Slovakia (Engel 1938-1956, Chvála 1981, 1994, 1997a, Chvála \& Wagner 1989, Pesarini et al. 1995, Grootaert et al. 2004). It probably occurs in southern Scandinavia (Chvála 1994).

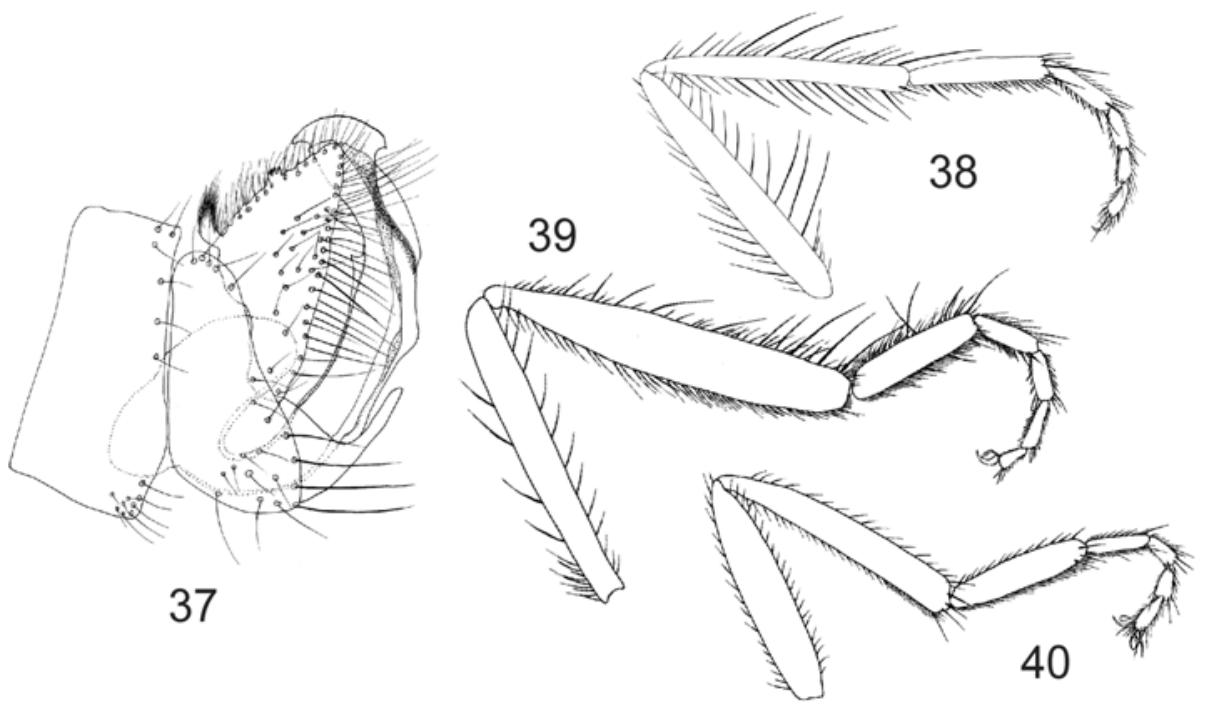

Figs 37-40. Empis (Empis) genualis. 37 - hypopygium, 38 - fore leg, 39 - hind leg, 40 - middle leg.

In Poland it has not been observed. One male was captured in a mid-forest meadow close to the town of Szczecinek in the Western Pomeranian Region on 17 August 1986 (leg. J. Majecki). This locality confirms the suggestion of Chvála (1994) that this species occurs in southern Scandinavia. Now the northern geographical limit of E. genualis occurs in Poland.

\section{Empis (Empis) gymnopoda Bezzi, 1908}

(Figs 41-43)

It is a species reported in Germany, the Czech Republic, Hungary, Austria, Switzerland, former Yugoslavia, Romania and Bulgaria (Engel 1938-1956, Chvála \& Wagner 1989, Ceianu 1992, Pesarini, et al. 1995, Chvála 1994, 1998). Information about its occurrence in Norway was incorrect and concerns another, very similar species, E. syrovatkai Chvála (Chvála 1994).

It is new for Poland. It was found 15 May 1987 in the Roztocze Region in the vicinity of Borowiec at the Tanew River and in the Chobot village in the Niepołomicka Forest 8 May 1976. In Poland probably occurs the northern geographical limit of this species. 


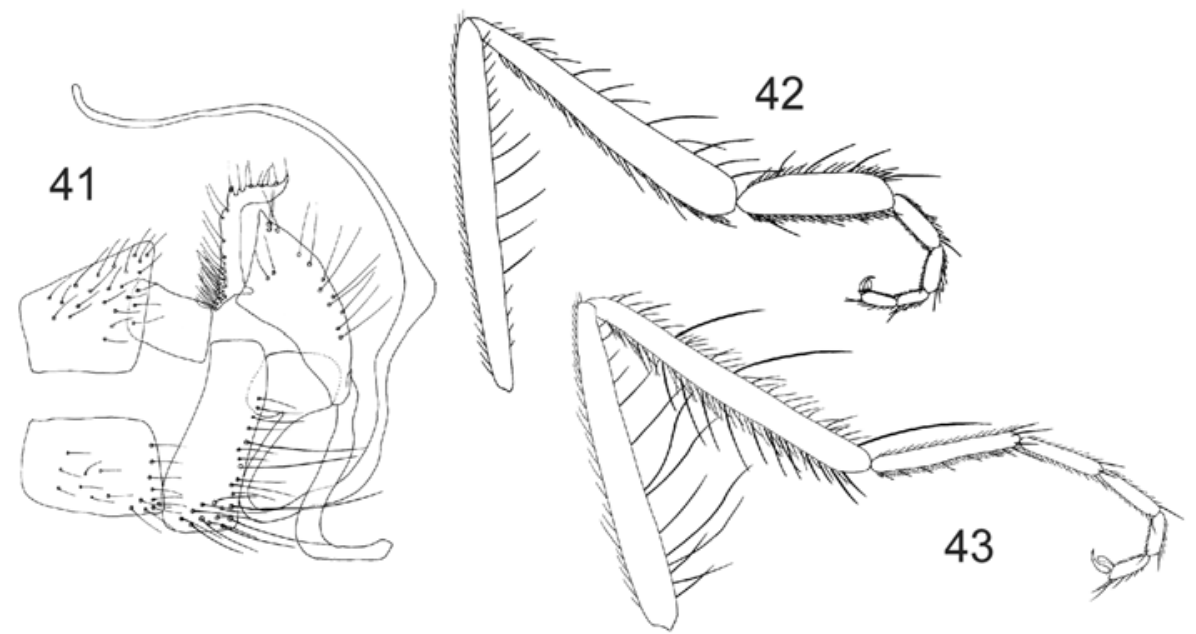

Figs 41-43. Empis (Empis) gymnopoda; 41 - hypopygium, 42 - hind leg, 43 - middle leg.

\section{Empis (Empis) planetica Collin, 1927}

(Figs 44-46)

It is a species reported on the British Isles, in southern Scandinavia,, Ireland, Holland, Belgium, Germany and the Czech Republic (Collin 1961, Chvála \& Wagner 1989, van der Goot 1989, Chvála 1994, Chvála \& Barták 2000, Plant 2003, Grootaert et al. 2004).

It is new for Poland.

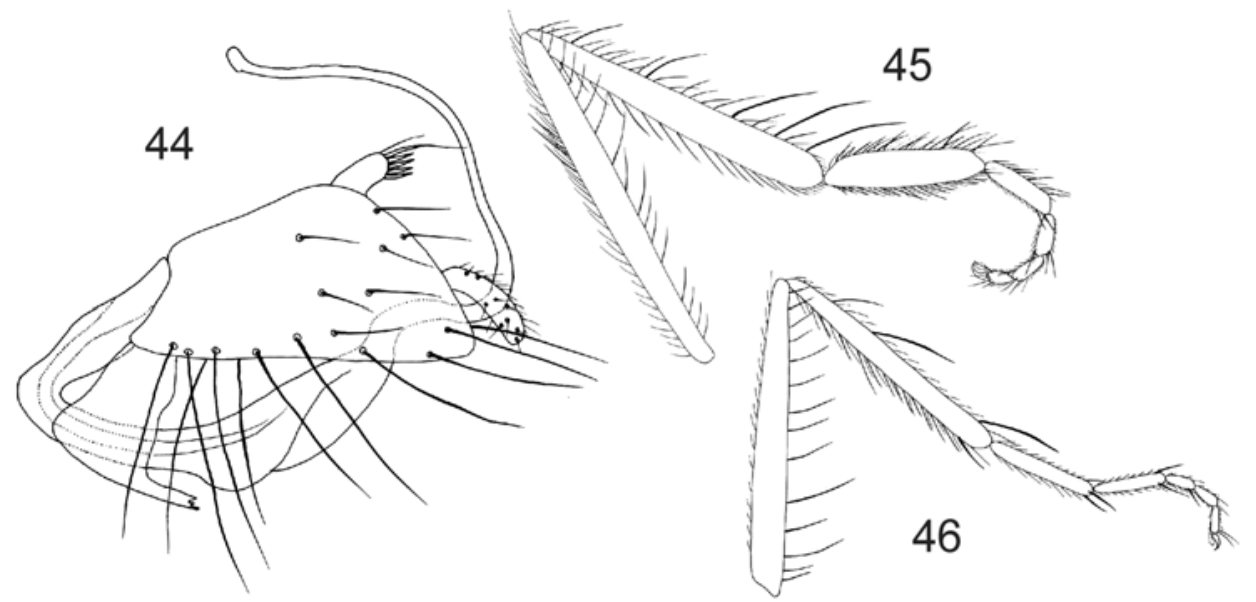

Figs 44-46. Empis (Empis) planetica; 44 - hypopygium, 45 - hind leg, 46 - middle leg

It is a spring species, collected by the 'yellow pans' method in May and June in the Radziejowice village near Warsaw, also in the Borecka Forest and in the Niepołomicka Forest in the village Chobot (leg. W. Krzemński). Probably in Poland occurs the eastern limit of this species. 


\section{Empis (Empis) melanotricha Loew, 1873}

(Figs 47-50)

It is a species reported in Holland, Belgium, Germany, the Czech Republic, Slovakia and also in northern Serbia and Romania (Engel 1938-1956, Chvála \& Wagner 1989, van der Goot 1989, Syrovátka 1991, Chvála 1994, Chvála \& Barták 2000, Grootaert et al., 2004). Probabably it occurs also in southern Scandinavia (Chvála 1994).

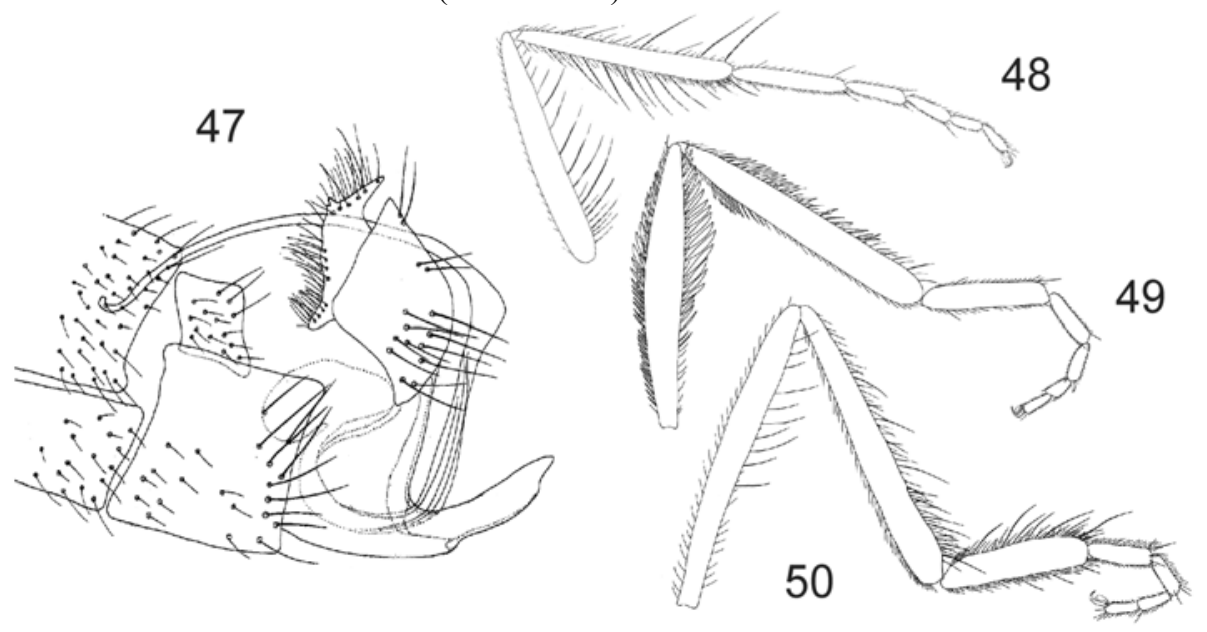

Figs 47-50. Empis (Empis) melanotricha; 47 - hypopygium, 48 - middle leg, 49 female hind leg, 50 - male hind leg.

In Poland it was noted in old faunal inventories only (Palaczyk 1991).

It is a spring species; one male was captured 18 May 1987 in the Roztocze National Park in a forest near the Jurgi village. Now in Poland the northern limit of this species occurs.

\section{Empis (Empis) woodi Collin, 1927}

(Figs 51-53)

It is a species reported on the British Isles, in Holland, Belgium, the Czech Republic, Slovakia, Hungary and also in Italy (Sardinia) (Collin 1961, Chvála \& Wagner 1989, Chvála 1994, Grootaert et al., 2004). Probably it occurs also in southern Scandinavia (Chvála 1994).

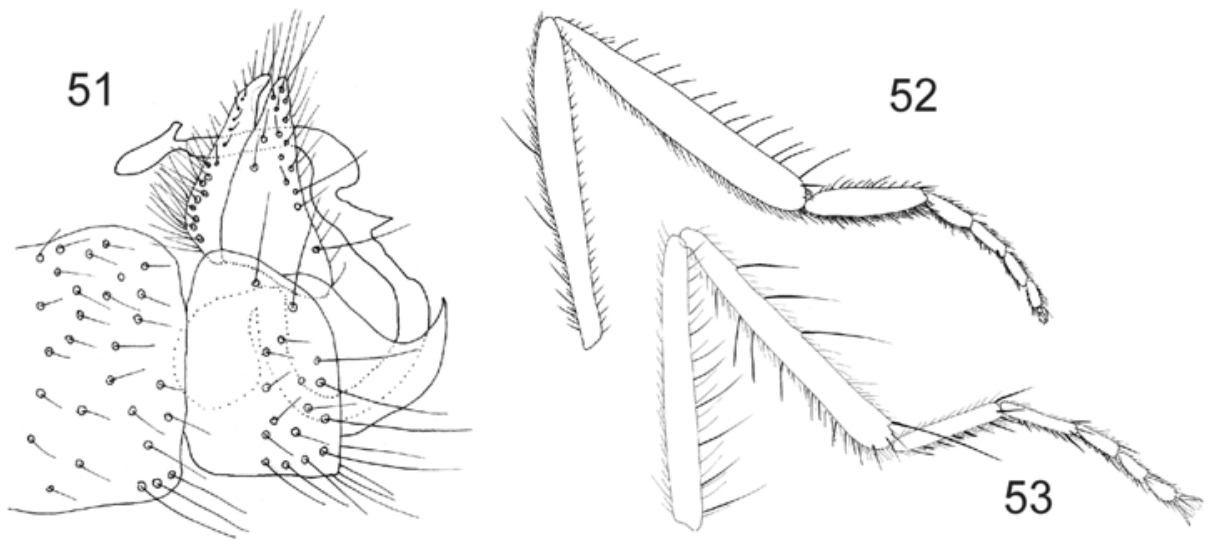

Figs 51-53. Empis (Empis) woodi; 51 - hypopygium, 52 - hind leg, 53 - middle leg. 
It is new for Poland.

It is a spring species. One male and one female were collected 13 May 1987 in the Roztocze Region in beech bushes growing on the banks of the Tarnawa River.

\section{Empis (Empis) bicuspidata Collin, 1927}

(Figs 54-56)

The species is typical for northern and central Europe. Noted from the British Isles, Belgium, Holland, Scandinavia and Bornholm, western and central Russia, the Czech Republic, Slovakia, Romania and Germany (Collin 1961, Chvála \& Wagner 1989, van der Goot 1989, Ceianu 1992, Chvála 1994, Grootaert et al. 2001, Plant 2003, Grootaert et al. 2004).
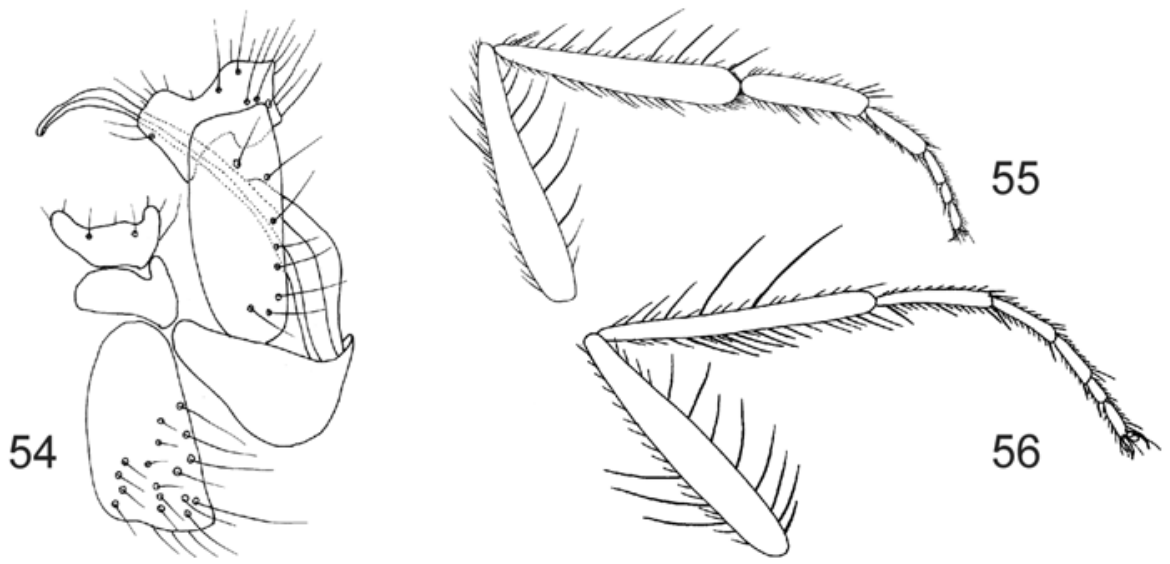

Figs 54-56. Empis (Empis) bicuspidate; 54 -hypopygium, 55 - hind leg, 56 - fore leg.

It is new for Poland. This spring species occurs in May and June. Recorded in the Swiętokrzyskie Mts, where it is rather common especially in bushes near streams and rivers and also in meadows, in the Roztocze Region, the Kampinoski National Park and on the Grabia River in Lutosławice village.

\section{Empis (Empis) nuntia Meigen, 1838}

(Figs 57-59)

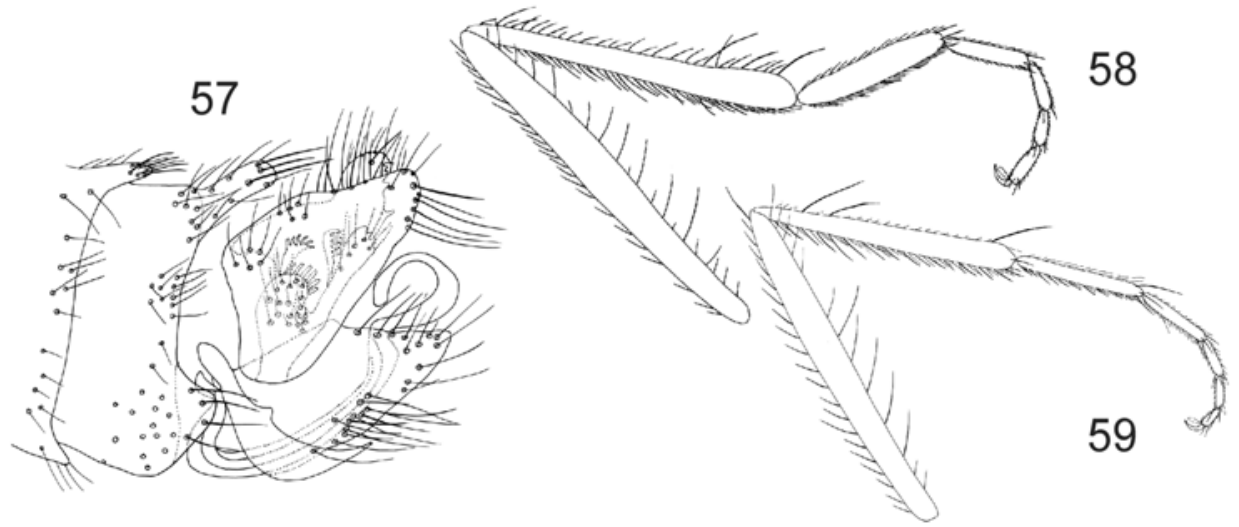

Figs 57-59. Empis (Empis) nuntia; 57 - hypopygium, 58 - hind leg, 59 - fore leg. 
It is a species reported on the British Isles, in Ireland, southern Scandinavia, Belgium, Holland, Germany, Switzerland, Hungary and the Czech Republic, where it is very common (Engel 1938-1956, Collin 1961, Chvála \& Wagner 1989, Chvála 1994, 1998, Meyr \& Filipinski 1998, Chvála et al.1998, Chvála \& Barták 2000, Barták \& Roháček 1999, Grootaert et al. 2001, Plant 2003).

It is new for Poland. One male was collected 30 May 1981 in the Świętkorzyskie Mts in the bushes growing on the banks of the stream in the Mirocice village.

\section{Empis (Empis) chioptera Meigen, 1838}

(Figs 60-63)

A species widely distributed in Europe. Noted from Scandinavia, Karelia, northern and middle Russia, the British Isles, Ireland, Holland, Belgium, France, Germany, the Czech Republic, Slovakia, Hungary and Switzerland; its southern limit of occurrence is located in Slovenia and northern Croatia (Engel 1938-1956, Collin 1961, Syrovátka 1977, Wéber 1981, Chvála \& Wagner 1989, van der Goot 1989, Meyer \& Speth 1995, Chvála 1994, 1998, Chvála et al. 1998, Barták \& Roháček 1999, Chvála \& Barták 2000, Grootaert et al. 2001, Plant 2003).
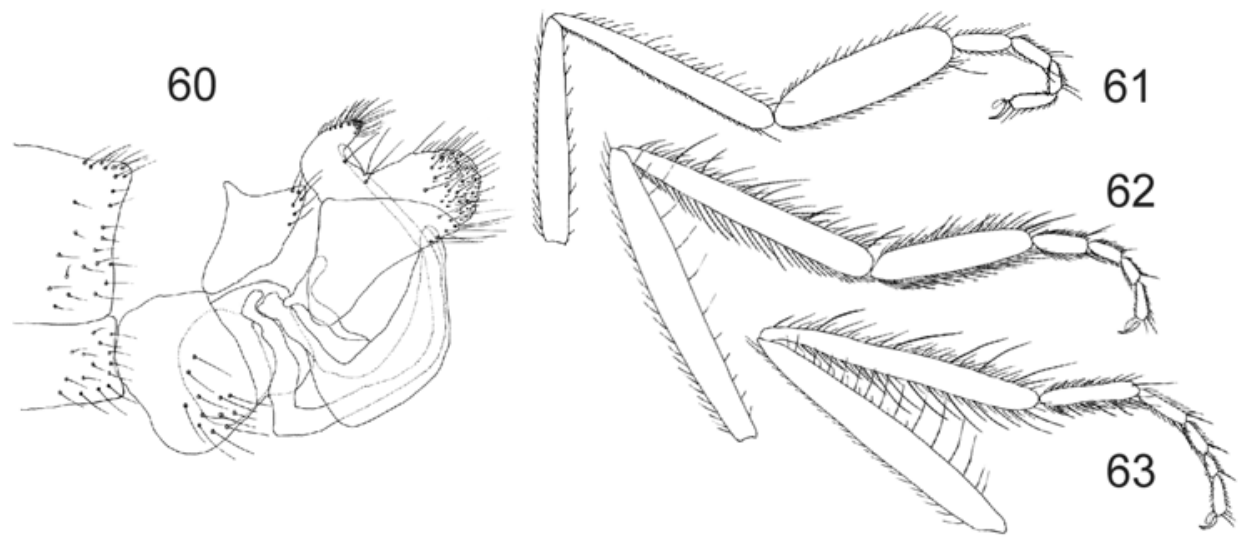

Figs 60-63. Empis (Empis) chioptera; 63 - hypopygium, 61 - fore leg, 62 - hind leg, 63 - middle leg.

In Poland it was noted in old faunal inventories (Palaczyk 1991) and also in the massive of the Babia Mount at the height of 700-800 m a.s.1. (Palaczyk \& Klasa 2003).

It is a spring species, occuring from May to the half of June, recorded in the Roztocze Region, the Świętokrzyskie Mts, where it is very common especially in the bushes growing on the banks of the streams, rivers and meadows, and also in the Małopolska Region near the sources of the Pilica River, in the Bieszczady Mts, where it was captured in the meadows lying by the side of the Terebowiec Stream at the height of about $900 \mathrm{~m}$ a.s.1., and also in Warsaw in the Mokotów quarter (leg. W. Mikołajczyk).

\section{Empis (Empis) beckeriana Engel, 1946}

(Figs 64-66)

It is a species reported in Germany, the Czech Republic and Austria (Engel 1938-1956, Chvála \& Wagner 1989).

It is new for Poland. 

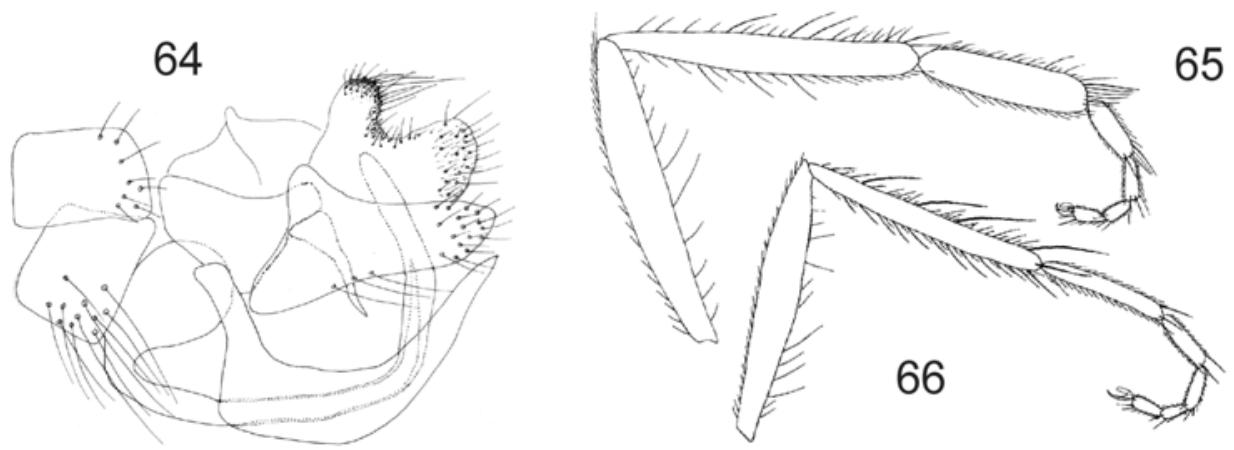

Figs 64-66. Empis (Empis) beckeriana, 64 - hypopygium, 65 - hind leg, 66 - middle leg.

It was recorded in the Świętokrzyskie Mts, where one male was collected 23 May 1985 in the Stołpiec Szlachecki village near Daleszyce, one male was collected 17 April 1984 in Grzegorzowice near Nowa Stupia and 15 males and 35 females were captured 10 May 1989 in the bushes in Warsaw in the Sadyba quarter by the researches of MZW. In Poland occurs the northern geographical limit of this species.

\section{Empis (Empis) prodromus Loew, 1867}

(Figs 67-69)

It is a species widely distributed in Europe, reported on the British Isles, in Belgium, Scandinavia, Karelia, northern and central Russia, the Czech Republic, Slovakia, Hungary, Austria, Germany, northern Italy and Moldavia (Engel 1938-1956, Collin 1961, Wéber 1981, Chvála \& Wagner 1989, Syrovátka 1991, Chvála 1994, 1998, Myer \& Speth 1995, Pesarini et al. 1995, Grootaert et al. 2001, Plant 2003).
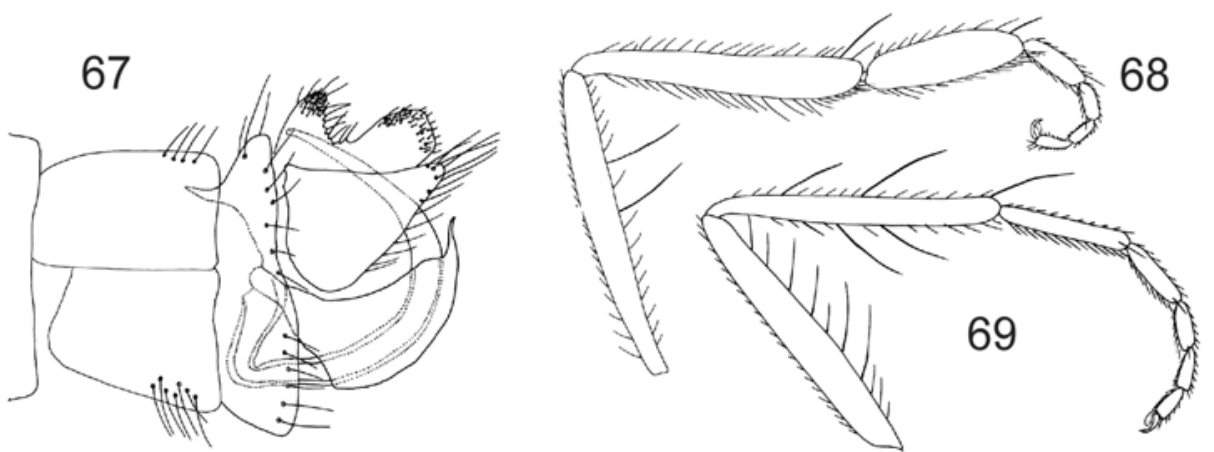

Figs 67-69. Empis (Empis) prodromus; 67 - hypopygium, 68 - hind leg. 69 - middle leg.

In Poland it was noted in old faunal inventories only (Palaczyk 1991).

It occurs from May to the half of July. Reported in the Roztocze Region, where in May it is very common on meadows and bushes especially growing on the banks of the Tanew River, in the Gorce Mts in the bushes near the Kamienica River, at the height of $800 \mathrm{~m}$ a.s.l., and also in Warsaw in the Bielany Forest (leg. W. Mikołajczyk) and in the bushes growing on the banks of affluents of the upper Pilica River. 


\section{Empis (Empis) dasyprocta Loew, 1867}

(Figs 70-72)

This species occurs in western and central Europe. Noted from the Atlantic coast from Spain to Holland and also from the Czech Republic, Slovakia and Austria (Engel 1938-1956, Chvála \& Wagner 1989, Syrovátka 1991, Chvála 1994). It probably occurs also in southern Scandinavia (Chvála 1994).

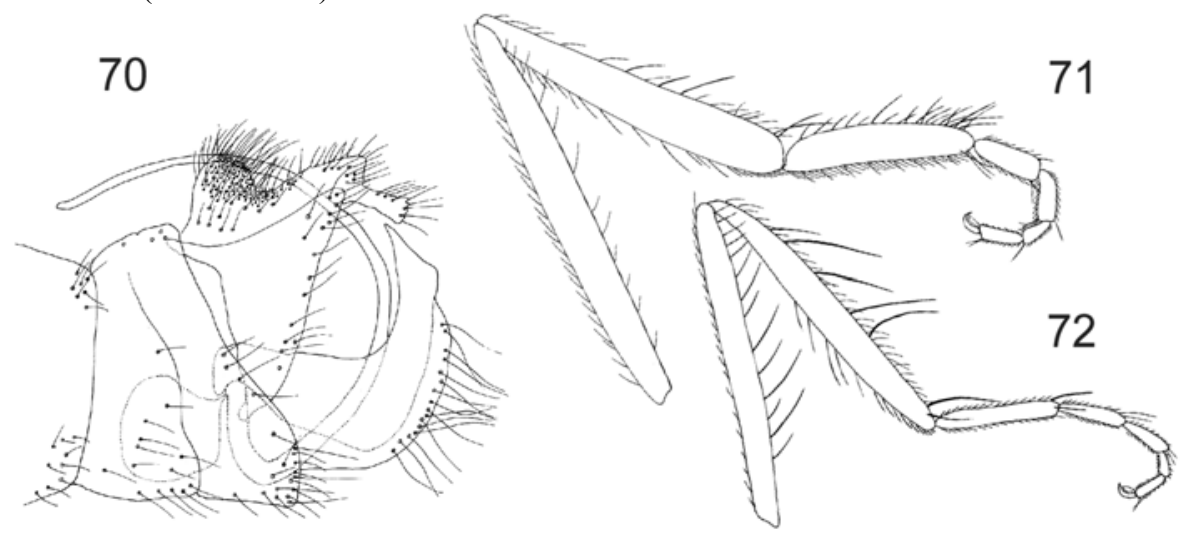

Figs 70-72. Empis (Empis) dasyprocta; 70 - hypopygium, 71 - hind leg, 72 - middle leg.

In Poland it was noted in old faunal inventories only (Palaczyk 1991).

One male and one female were collected 17 May 1984 in the Świętokrzyskie Mts in the Grzegorzowice village near Nowa Słupia. In Poland occurs the northern geographical limit of this species.

\section{Empis (Empis) caudatula Loew, 1867}

(Figs 73-76)

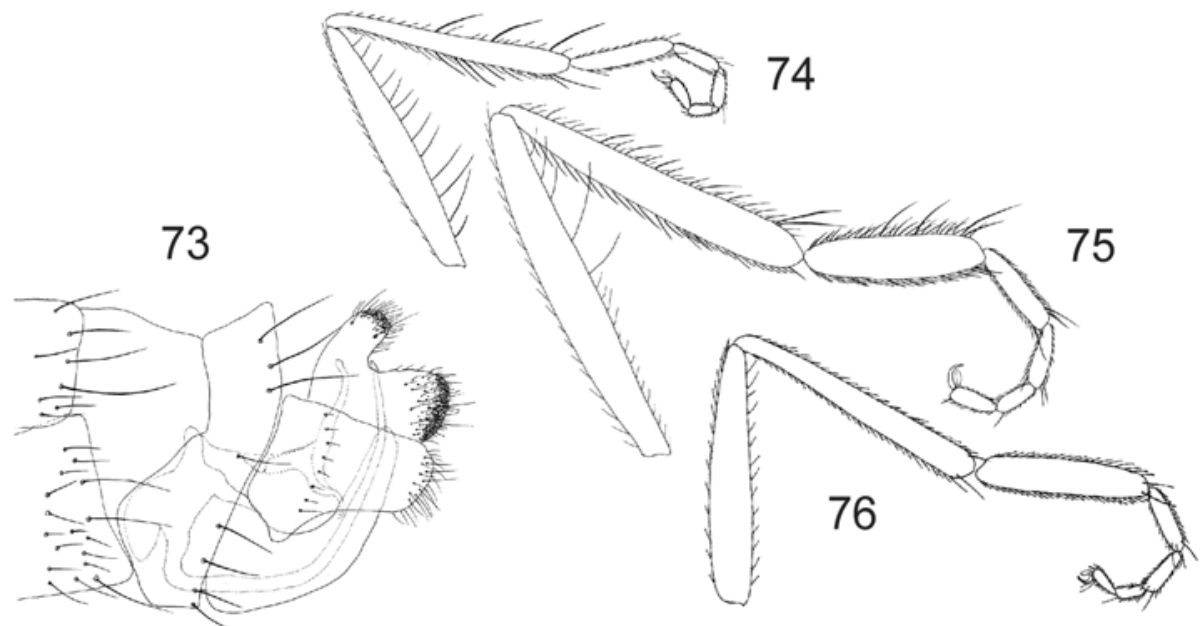

Figs 73-76. Empis (Empis) caudatula; 73 - hypopygium, 74 - middle leg, 75 - hind leg, 76 - fore leg. 
The species is reported from southern Scandinavia, the British Isles, Germany, Belgium, the Czech Republic and Slovakia, Bielarus, Ukraine, Russia, Austria, Hungary, northern France and northern regions of former Yugoslavia (Engel 1938-1956, Collin, 1961, Chvála \& Wagner 1989, Syrovátka 1991, Chvála 1994, 1998, Barták \& Roháček 1999, Chvála \& Barták 2000, Grootaert et al. 2001, Plant 2003).

In Poland it was reported in old faunal inventories (Palaczyk 1991) and also in the massive of the Babia Mount, at the height of $730 \mathrm{~m}$ a.s.l. (Palaczyk \& Klasa 2003).

It occurs from May to August; it was recorded in the saline habitat in Solec Kujawski and Ciechocinek, in Warsaw (in Ursynów, Łazienki quarters) and in the Ogród Saski where it was obtained by the 'yellow pans' method, and also in the Kampinoski National Park and in the Bieszczady Mts in the bushes growing on the banks of the Cisna Stream at the height of about $600 \mathrm{~m}$ a.s.1.

\section{Empis (Empis) aestiva Loew, 1867}

(Figs 77-79)

The species is reported from the British Isles, Ireland, Belgium, Holland, Scandinavia, Russia, Germany, Switzerland, the Czech Republic and Slovakia, Austria, Slovenia and also Portugal (Azores Islands) (Engel 1938-1956, Collin 1961, Chvála \& Wagner 1989, van der Goot 1989, 1990, Syrovátka 1991, Ceianu 1992, Chvála 1994, 1998, Meyer \& Filipinski 1998, Chvála et al. 1998, Chvála \& Barták 2000, Grootaert et al. 2001, Plant 2003).
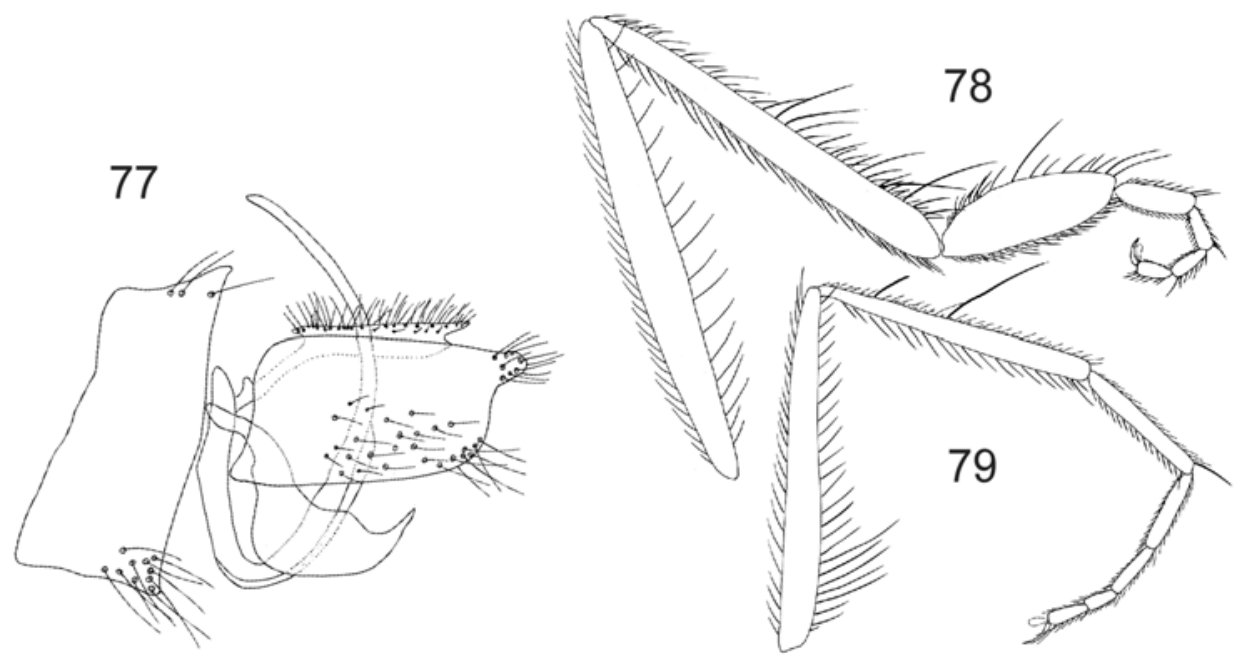

Figs 77-79. Empis (Empis) aestiva; 77 - hypopygium; 78 - hind leg, 79 - middle leg.

In Poland it was reported in old faunal inventories (Palaczyk 1991) and also in the massive of the Babia Mount, at the height of 750-1050 m a.s.l. (Palaczyk \& Klasa 2003).

The species is very common in July and August, it occurs also in September. Recorded in the West Pomeranian Region near Szczecinek (leg. J. Majecki), in the Słuchowo village near Białogóra, in bushes growing on the banks of the Bychowska Struga River, in the Las Piwnicki in the vicinity of Torun (leg. M. Szadziewska), in the Borecka Forest, where it was collected by the 'yellow pans' method by the researchers of MZW, in Warsaw in the Ogród Saski and the Ursynów quarter and also in the vicinity of Spała, in the Roztocze Region, the Będkowska Valley (near Kraków) (leg. W. 
Krzemiński), the Izerskie Mts (leg. W. Kittel), the Świętokrzyskie Mts, the Gorce Mts near Jaszcze Stream at the height of about $800 \mathrm{~m}$ a.s.l. (leg. J. Wiedeńska) and in the Bieszczady Mts in the meadows in the vicinity of the Bukowiec village at the height of about $500 \mathrm{~m}$ a.s.l.

\section{Empis (Empis) alpicola Strobl, 1893}

(Figs 80-82)

A mountain species known from the Alps (Austria, Italy), East Carpathians (Slovakia, Romania) and Pyrenean (Spain) (Engel 1938-1956, Ceianu 1992, Chvála \& Wagner 1989).
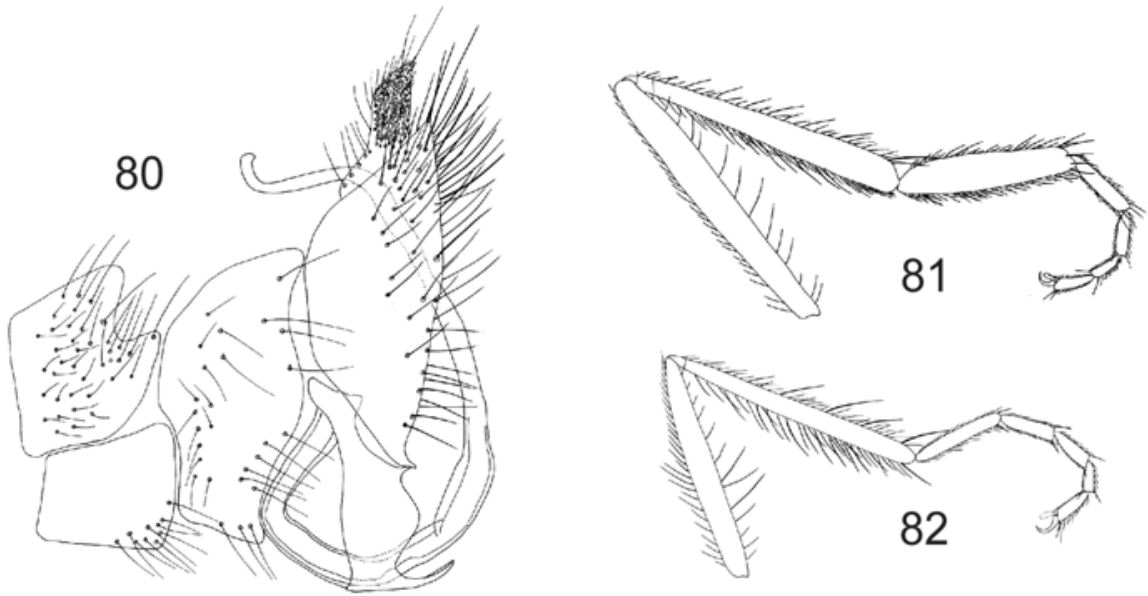

Figs 80-82. Empis (Empis) alpicola; 80 - hypopygium, 81 - hind leg, 82 - middle leg.

It is new for Poland.

Reported from the Bieszczady Mts, were one male was collected 12 June 1984 near Zwór Stream at the height of $1200 \mathrm{~m}$ a.s.1. In Poland occurs the northern geographical limit of this mountainous southern species.

\section{Empis (Empis) anfractuosa Mik, 1884}

(Figs 83-85)
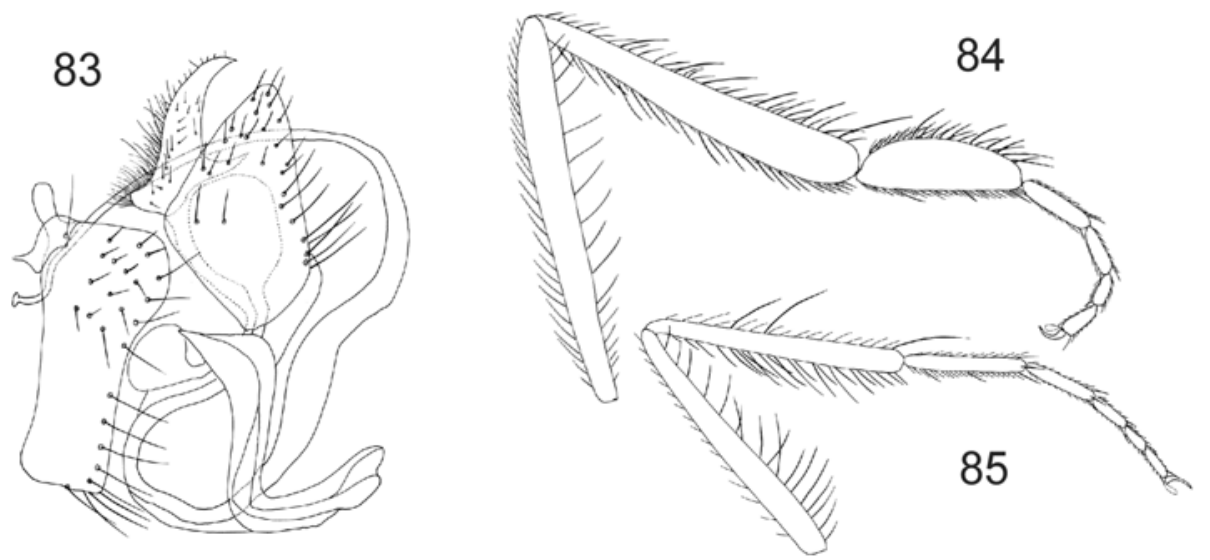

Figs 83-85. Empis (Empis) anfractuosa; 83 - hypopygium, 84 - hind leg, 85 - middle leg. 
The species is reported from Germany, Austria, the Czech Republic and Romania (Engel 1938-1956, Chvála \& Wagner 1989, Ceianu 1992).

It is new for Poland.

It occurs in April and May and also in August, probably the second generation. Recorded in the Roztocze Region, Torun, Koniecpol near the Pilica River and Wrzeciono near Warsaw. In Poland occurs probably the northern limit of this species.

\section{Empis (Empis) apfelbecki Strobl, 1898}

(Figs 86-88)

The species is described from Bosnia and Herzegovina from the vicinity of Jablanica, and one male is recorded in south Austria (Engel 1938-1956, Chvála \& Wagner 1989).

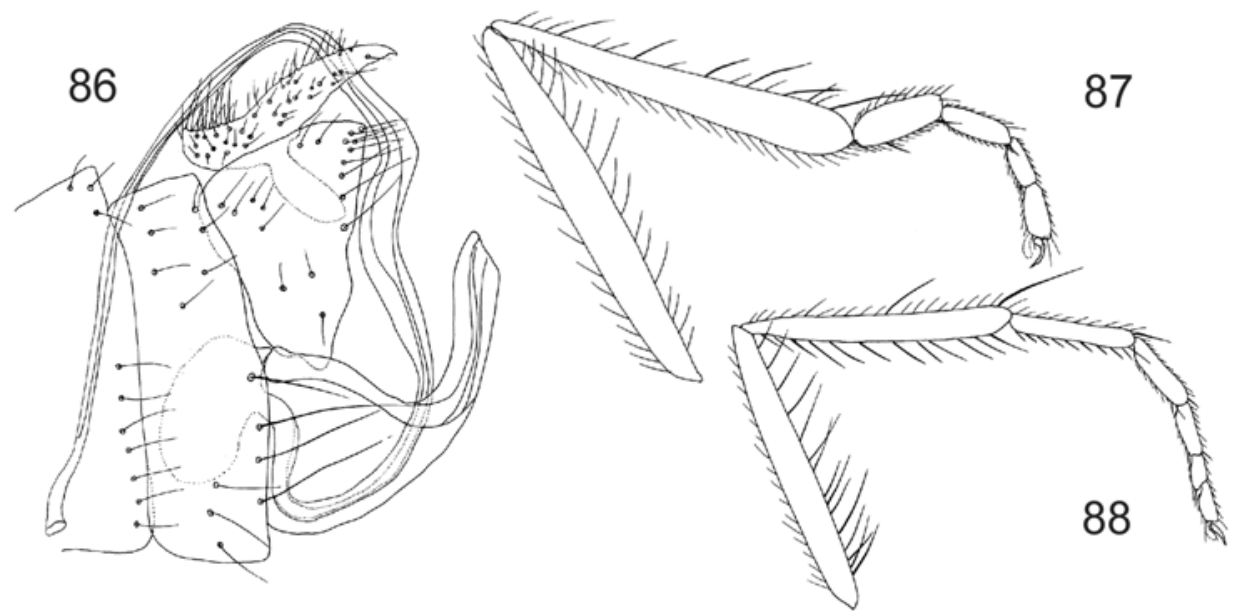

Figs 86-88. Empis (Empis) apfelbecki; 86 - hypopygium, 87 - hind leg, 88 - middle leg.

It is new for Poland.

A few males were collected in May 1987 in the Roztocze Region on the bushes growing on the banks of the Tanwia River and near the sources of the Niepryszka stream. In Poland occurs probably the northern limit of this species.

\section{Empis (Empis) nigripes Fabricius, 1794}

(Figs 89-91)

The species is very common throughout Europe together with Scandinavia and Russia, where it occurs also in western Siberia; rare in the Mediterranean Region (Engel 1938-1956, Collin 1961, Wéber 1981, Chvála \& Wagner 1989, van der Goot 1989, Ceianu 1992, Chvála 1994, 1997b, 1998, Chvála et al.1998, Meyer \& Filipinski 1998, Barták \& Roháček 1999, Chvála \& Barták 2000, Grootaert et al. 2001, Plant 2003, Grootaert et al., 2004).

In Poland it was noted in old faunal inventories (Palaczyk 1991) and also in the massive of the Babia Mount (Palaczyk \& Klasa 2003).

The spring species occuring in May and June is the commonest species of the genus in Poland. Very common in the Świetokrzyskie Mts, where it occurs in the meadows, near streams, rivers, sometimes flying in a small swarms and also in the Roztocze Region, the Kampinoski National Park, bushes on the banks of the Pilica River in Warka village, the upper Widawka River, in the vicinity of Warsaw in the Radziejowice village and in Warsaw in the 
Łazienki Park, where it was obtained by the 'yellow pans' method by the researchers of MZW, in the Sudety Mts near the Kamionka stream (leg. M. Golańska), in the Bieszczady region in bushes on the banks of the San River in the Dwerniczek village and in the Wetlina village at the height of about $500 \mathrm{~m}$ a.s.l.

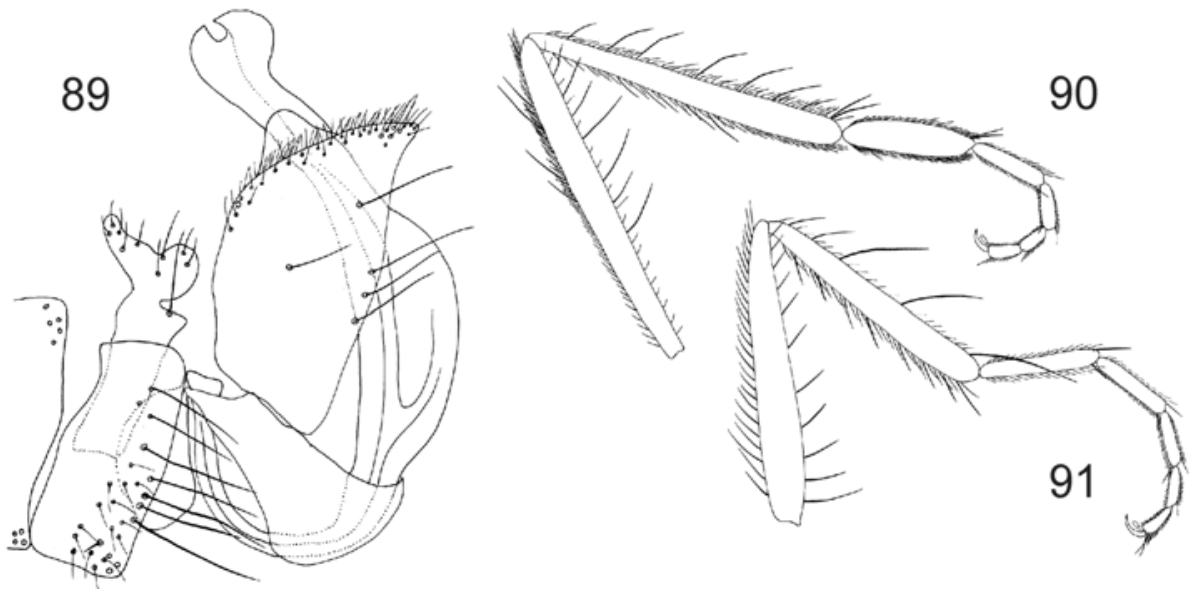

Figs 89-91. Empis (Empis) nigripes; 89 - hypoygium, 90 - hind leg, 91 - middle leg.

\section{Empis (Empis) maerens Loew, 1867}

(Figs 92-94)

The mountainous species is described from the Austrian Alps and known only from Austria and Switzerland (Engel 1938-1956, Chvála \& Wagner 1989, Syrovátka 1991, Chvála et al. 1998).

It is new for Poland.

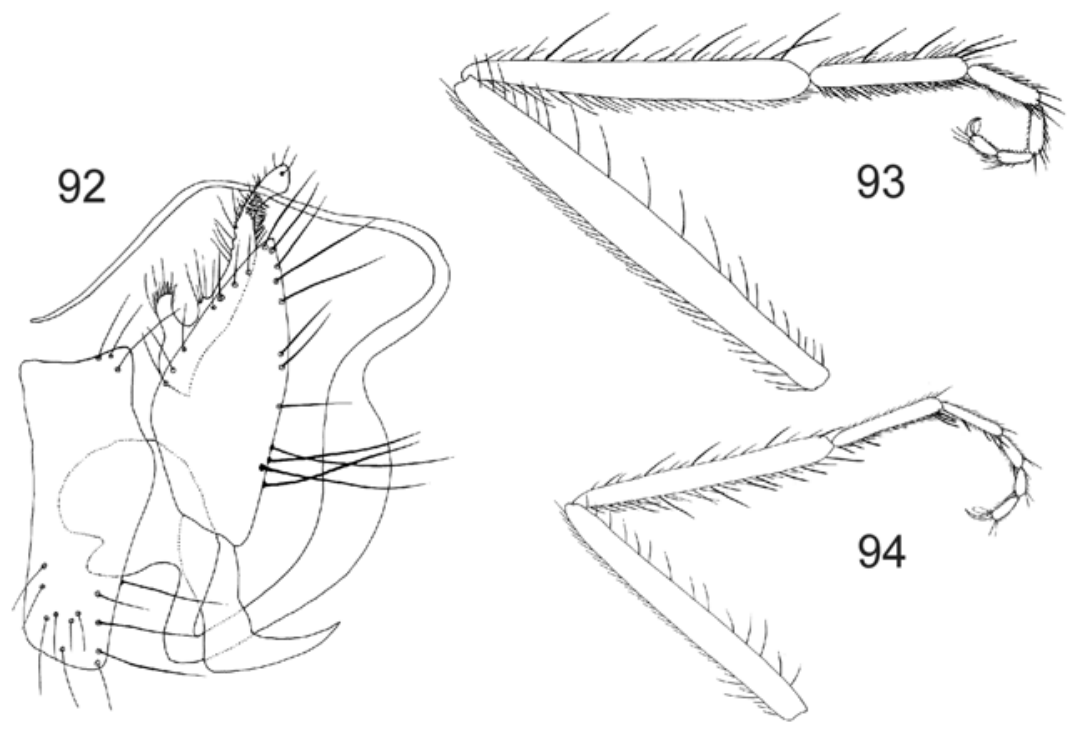

Figs 92-94. Empis (Empis) maerens; 92 - hypopygium, 93 - hind leg, 94 - middle leg. 
One male was collected 13 July 1987 in the Tatra Mts near the Olczysko spring at the height of $1100 \mathrm{~m}$ a.s.l. and one male was collected 23 July 1986 in the Bieszczady Mts in bushes growing on the banks of the Rzeka Stream at the height of $700 \mathrm{~m}$ a.s.1. In Poland occurs the northern limit of this species.

\section{Empis (Empis) filata Loew, 1873}

(Figs 95-97)

The species is reported from Slovakia, former Yugoslavia and Romania (Engel 1938-1956, Chvála \& Wagner 1989, Syrovátka 1991, Ceianu 1992).
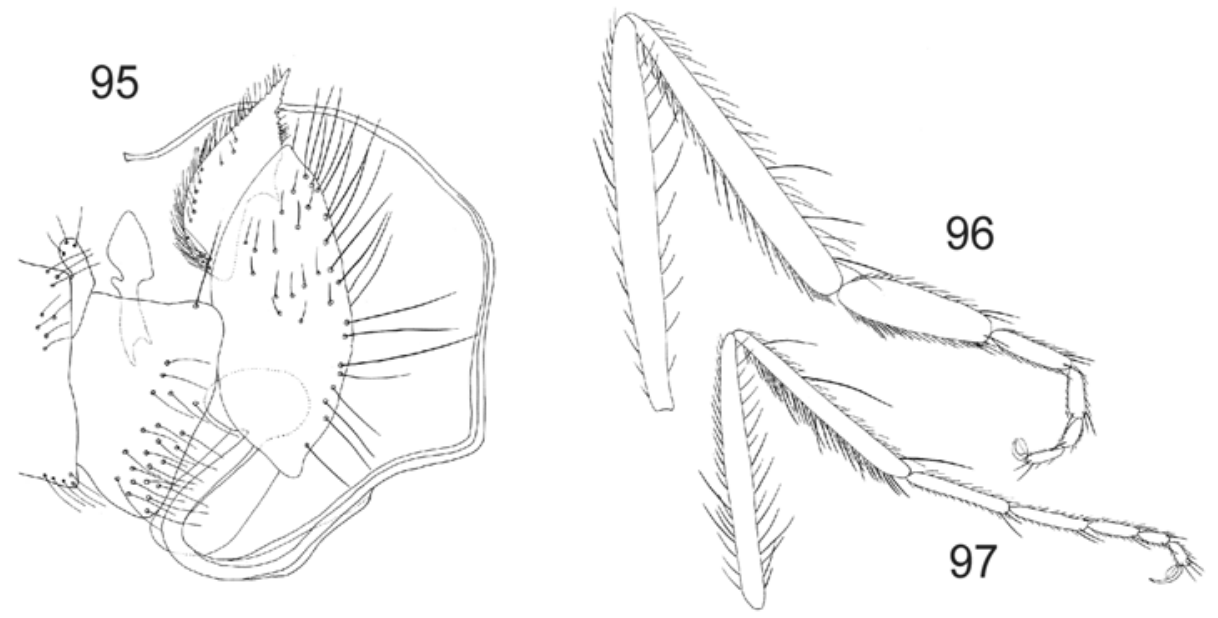

Figs 95-97. Empis (Empis) filata; 95 - hypopygium, 96 - hind leg, 97 - middle leg.

It is new for Poland. The spring species occurs from April to June. Recorded in the Świętokrzyskie Mts, the Roztocze Region in a meadow lying by the side of the Tanew River and in an oak forest in the vicinity of Zamość (leg. W. Mikołajczyk) and also in the Bieszczady Mts, where it is common at the height of about $500 \mathrm{~m}$ a.s.l., the Niepołomicka Forest in the Chobot village (leg. W. Krzemiński), Toruń (leg. M. Szadziewska). In Poland occurs the northern limit of this species.

\section{Empis (Coptophlebia) hyalipennis Fallen, 1816}

(Figs 98-99)
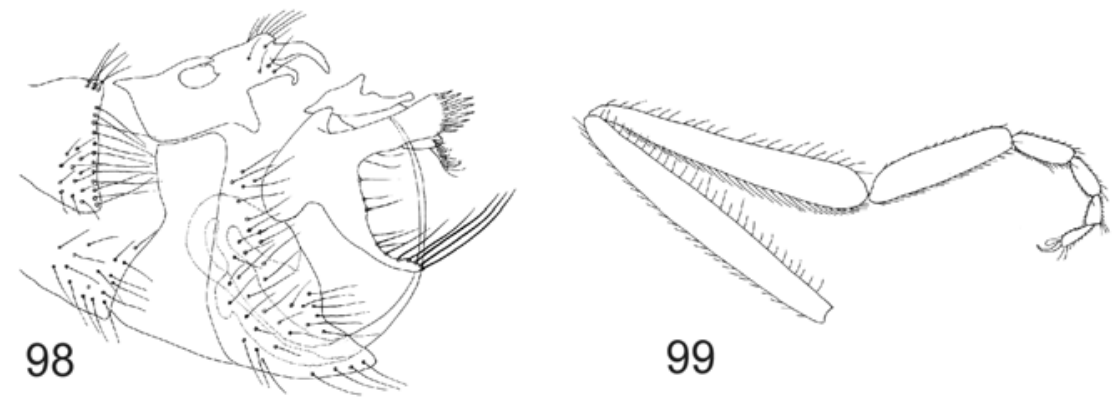

Figs 98-99. Empis (Coptophlebia) hyalipennis; 98 - hypopygium, 99 - hind leg. 
The species is widespread in all Europe, from Scandinavia and north and west Russia, the British Isles, Germany, the Czech Republic, Slovakia and Austria to the northern regions of Italy, former Yugoslavia, Romania and Spain (Engel 1938-1956, Collin 1961, Chvála 1981, 1994, Chvála \& Wagner 1989, Ceianu 1992, Chvála \& Barták 2000, Plant 2003).

In Poland it was noted in old faunal inventories (Palaczyk 1991) and also in Bieszczady from the Hulskie village at the height of $550 \mathrm{~m}$. a.s.l. (Klasa et al. 2000). Collected in the Bieszczady Mts, one male 22 July 1986 in the meadow near Beskidnik Stream at a height of 800 m. a.s.l., one male 30 July 1984 in bushes on the banks of the Wetlina stream in the Kalnica village at the height of $600 \mathrm{~m}$ a.s.l. (leg. M. Golańska).

\section{Empis (Coptophlebia) impennis Strobl, 1902}

(Figs 100-102)

The species is also known as E. melaena (Bezzi, 1908), especially in old publications. Reported from the British Isles, Holland, Germany, the Czech Republic, Austria, Hungary, Switzerland, France and Croatia (neighbourhood of Split). (Engel 1938-1956, Collin 1961, Wéber 1981, Chvála \& Wagner 1989, van der Goot 1989, Chvála 1998, Chvála et al. 1998, Plant 2003).
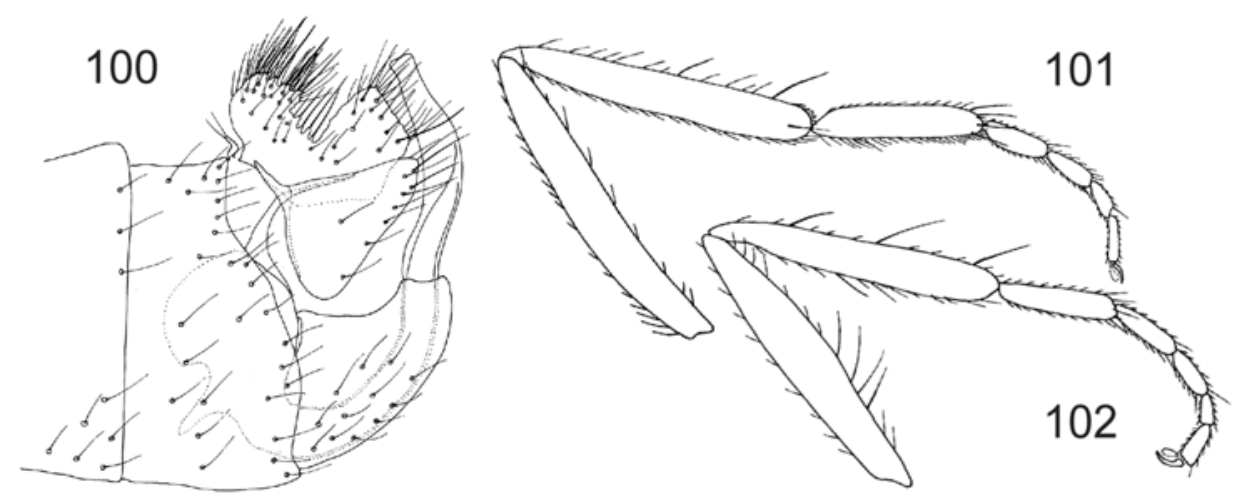

Figs 100-102. Empis (Coptophlebia) impennis; 100 - hypoygium, 101 - hind leg, 102 - middle leg.

In Poland noted from the massive of the Babia Mount at the height of $730 \mathrm{~m}$ a.s.l. (Palaczyk \& Klasa 2003).

One male was collected 26 June 1987 in Warsaw in Sadyba by the 'yellow pans' method, one male and three females 17 July 1984 in the Świętokrzyskie Mts in the Grzegorzowice village near Nowa Słupia.

\section{Empis (Coptophlebia) albinervis Meigen, 1822}

(Figs 103-105)

The species is widely distributed in Europe; noted from Scandinavia, Ireland, the British Isles, Germany, the Czech Republic, Slovakia, Belgium, Holland, Austria, Italy, former Yugoslavia and France together with Corsica (Engel 1938-1956, Collin 1961, Wéber 1981, Chvála \& Wagner 1989, Wehlitz 1992, Pesarini et al. 1995, Chvála 1994, Barták \& Roháček 1999, Chvála \& Barták 2000, Grootaert et al. 2001, Plant 2003).

In Poland it was noted in old faunal inventories (Palaczyk 1991) and also from the massive of the Babia Mount at the height of $730 \mathrm{~m}$ a.s.l. (Palaczyk \& Klasa 2003), the Bieszczady Mts in Liskowate near Krościenko at the height of $500 \mathrm{~m}$ a.s.l. (Klasa et al. 2000). 


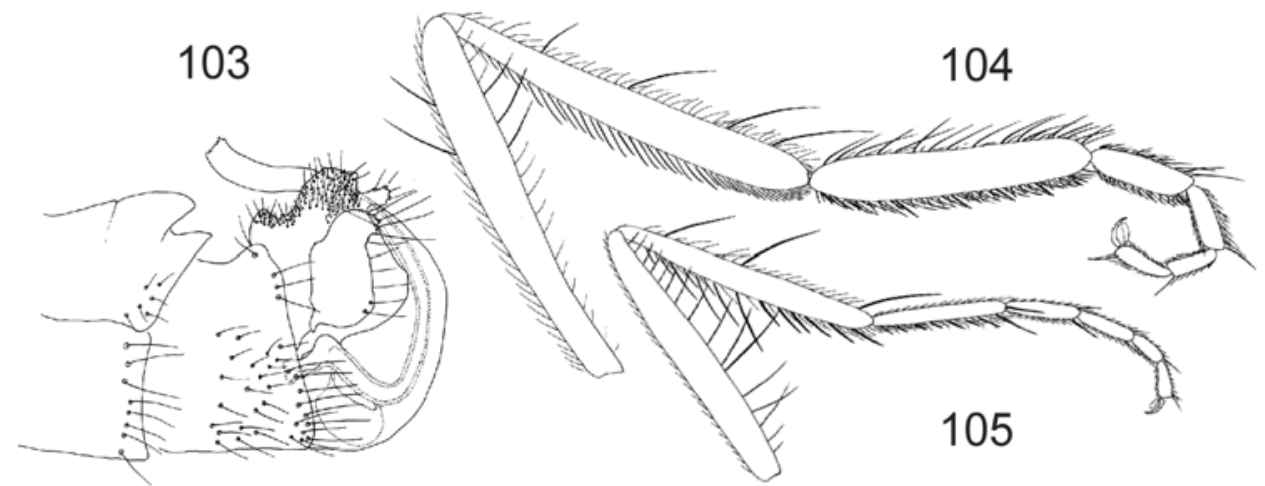

Figs 103-105. Empis (Coptophlebia) albinervis; 103 - hypopygium, 104 - hind leg, 105 - middle leg.

One male was collected 15 June 1983 in the Świętokrzyskie Mts in bushes growing on the affluents of the Belnianka Stream in the Huta Szklana village.

\section{Empis (Coptophlebia) vitripennis Meigen, 1822}

(Figs 106-108)

The species is widely distributed in Europe. Reported on the British Isles, in south Scandinavia, Belgium, Holland, Germany, the Czech Republic, Slovakia, Spain and France (Engel 1938-1956, Collin 1961, Chvála 1981, 1994, 1997a, 1997b, Chvála \& Wagner 1989, van der Goot 1989, Grootaert et al. 2001, Plant 2003). Frey (1945) informs that this species occurs also on the Azores Islands but Chvála (1994) thinks that this information has to be confirmed.
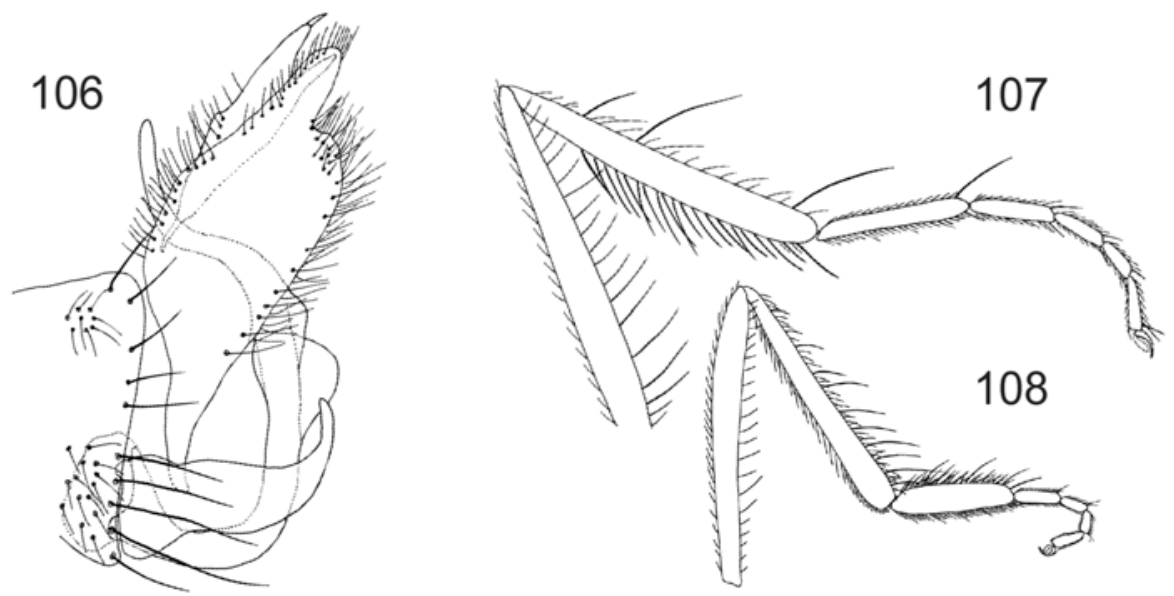

Figs 106-108. Empis (Coptophlebia) vitripennis; 106 - hypopygium, 107 - hind leg, 108 - middle leg.

In Poland it was noted in old faunal inventories only (Palaczyk 1991).

It is a species recorded in the Zwierzyniec Reserve of the Roztocze Region between August and early October, both in bushes on the shore of the Pond Echo and on a lake shore close to the village of Biały Bór as well as in the forest, where it was collected by the 'yellow pans' method; besides, in August at the town of Górczyn in the Western Pomerania Region, in the 
source section of a stream outflowing to the Baltic Sea and in bushes on the shores of midforest lakes in the vicinity of the town of Szczecinek (leg. J. Majecki).

\section{Empis (Coptophlebia) pilimana Loew, 1869}

(Figs 109-111)

The species is noted from south Scandinavia, Holland, Germany, Switzerland, the Czech Republic, Austria and Romania (Engel 1938-1956, Chvála \& Wagner 1989, Chvála 1994).
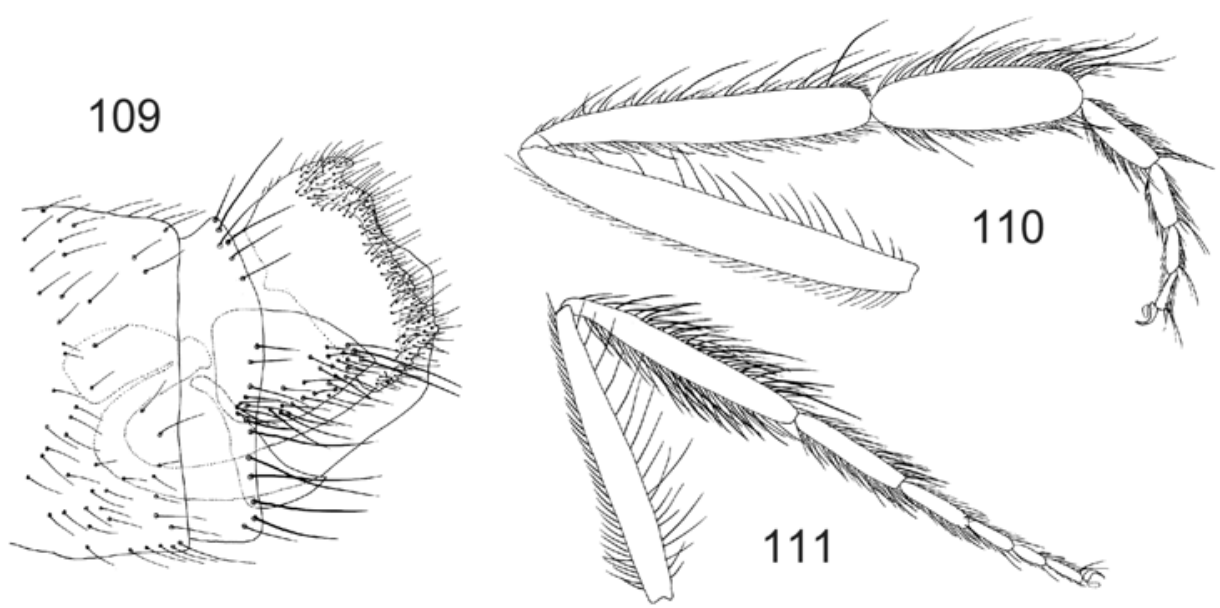

Figs 109-111. Empis (Coptophlebia) pilimana; 109 - hypopygium, 110 - hind leg, 111 - middle leg.

In Poland it was noted in old faunal inventories only (Palaczyk 1991).

One male was collected by the 'yellow pans' method 8 September 1987 in Warsaw in the Sadyba quarter by the researchers of MZW

\section{Empis (Xanthempis) lutea Meigen, 1804}

(Figs 112-113)

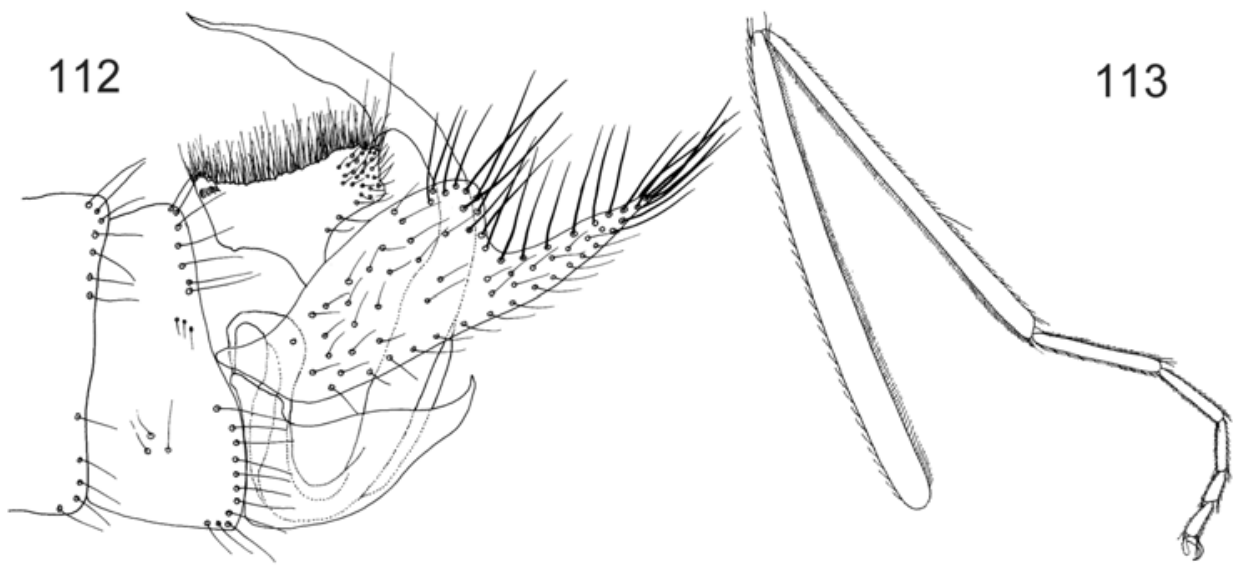

Figs 112-113. Empis (Xanthempis) lutea; 112 - hypopygium, 113 - hind leg. 
The species is very common in all Europe, together with the British Isles and Scandinavia but it is not reported in Russia (Engel 1938-1956, Collin 1961, Chvála \& Wagner 1989, Ceianu 1992, Wehlitz 1992, Chvála 1994, 1996, 1998, Pesarini et al. 1995, Chvála et al. 1998, Chvála \& Barták 2000, Grootaert et al. 2001).

In Poland it was noted in old faunal inventories (Palaczyk 991) and also reported from the massive of the Babia Mount, where it was collected in the Zawoja-Widła village at the height of $600 \mathrm{~m}$ a.s.1. (Palaczyk \& Klasa 2003). One male and 7 females were captured by light trapping in the vicinity of Lakelets Duszatyńskie in the Bieszczady Mts on 3 August 1996 (leg. B. Szczęsny).

\section{Empis (Xanthempis) concolor Verall, 1872}

(Fig. 114)

The species is noted from the British Isles, Belgium, Holland, southern Scandinavia, Germany, Switzerland, Romania and also Spain (Engel 1938-1956, Collin 1961, Chvála \& Wagner 1989, Chvála 1981, 1994, Ceianu 1992, Chvála et al. 1998).

It is new for Poland. One male was collected 4 July 1987 in the Roztocze Region in a beech forest near the Szczebrzeszyn village.

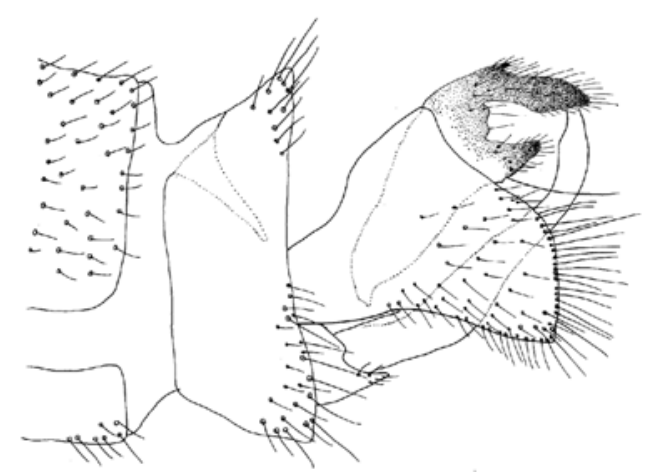

Fig. 114. Empis (Xanthempis) concolor, hypopygium.

\section{Empis (Xanthempis) stercorea Linnaeus, 1761}

(Fig. 115)

This species is known from the whole eastern part of the Palaearctic, together with the British Isles and Scandinavia, except for the Far East and Middle Asia. (Engel 1938-1956, Collin 1961, Chvála \& Wagner 1989, van der Goot 1989, Ceianu 1992, Wehlitz 1992, Chvála 1994, 1996, 1998, Pesarini et al. 1995, Meyr \& Speth 1995, Chvála et al. 1998, Meyer \& Filipinski 1998, Barták \& Roháček 1999, Chvála et al. \& Barták 2000, Grootaert et al. 2001, Plant 2003).

In Poland it was noted in old faunal inventories (Palaczyk 1991) and also in the Białowieża Primeval Forest (Palaczyk 1991), in the Bieszczdy Mts (Klasa et al. 2000) and in the massive of the Babia Mount, where it is common at the height of about $600-900 \mathrm{~m}$ a.s.1. (Palaczyk \& Klasa 2003).

It is one of the most common species from the genus Empis in our country. It occurs in May and June in lowland, in the Białowieża Primeval Forest (Topiło forestry) collected by researchers of the MZW in mass especially by the 'yellow pans' method in the tree tops, undergrowth, on meadows and in bushes near riversides, recorded also in the Świętokrzyskie 
Mts, the Roztocze Region, in the vicinity of Warsaw, in the botanic garden in Łódź (leg. K. Kowalczyk), and the Gorce Mts at the height of about $800 \mathrm{~m}$ a.s.1.

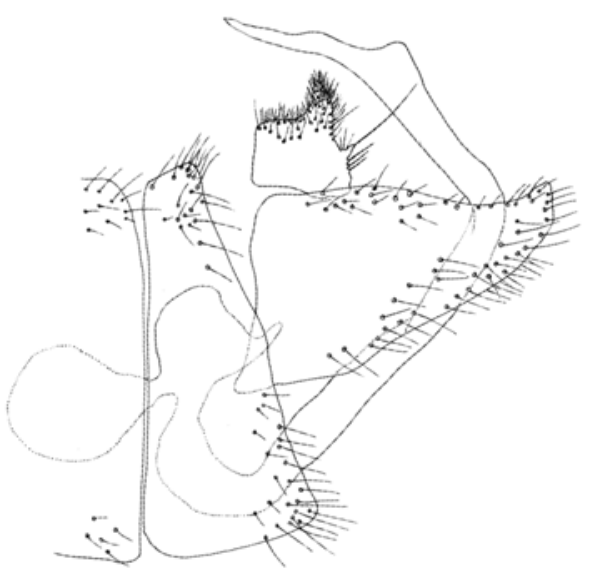

Fig. 115. Empis (Xanthempis) stercorea, - hypopygium.

\section{Empis (Xanthempis) aemula Loew, 1873}

(Fig. 116)

The species is reported from the British Isles, southern Scandinavia, Belgium, the Czech Republic, Slovakia, Germany and Romania (Engel 1938-1956, Collin 1961, Chvála \& Wagner 1989, Ceianu 1992, Chvála 1994, 1997a, 1997b, Meyer \& Filipinski 1998, Chvála \& Barták 2000, Grootaert et al. 2001, Plant 2003).

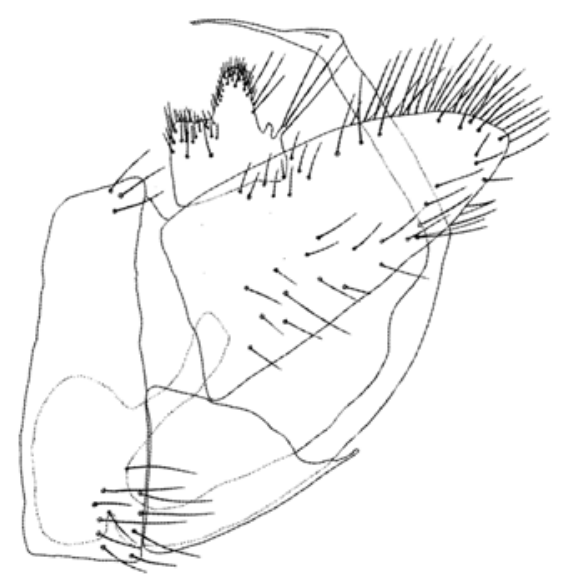

Fig. 116. Empis (Xanthempis) aemula, hypopygium.

In Poland it was noted in old faunal inventories (Palaczyk 1991) and also from the massive of the Babia Mount, where it was collected at the height of 700-1050 m a.s.l. (Palaczyk \& Klasa 2003). This species is as common, and sometimes even more common as E. stercorea, 
and often they are captured together. E. aemula is more often than E. stercorea recorded in the mountains. It occurs in May and June in the Białowieża Primeval Forest (Topiło forestry), where it was collected using the 'yellow pans' method in tree crowns and undergrowth, as well as in the meadows and in bushes.

In July it also occurs at the riverside of the Grabia River, in the Kampinoski National Park, the Niepołomicka Forest, the Borecka Forest, in the Roztocze Region, in the Sudety Mts, in the Gorce Mts at the height of $900 \mathrm{~m}$ a.s.l., in the Bieszczdy Mts in bushes growing on the banks of the San and Wetlina Rivers at the height of about 500-600 m a.s.l. and in the Tatra Mts at the height of about $1000 \mathrm{~m}$ a.s.l.

\section{Empis (Xanthempis) univittata Loew, 1867}

(Figs 117-118)

The species is reported from Scandinavia, Germany, the Czech Republic, Austria, Switzerland, Romania and also the far eastern part of Russia (Engel 1938-1956, Chvála, Wagner 1989, Ceianu 1992, Chvála 1994, 1996, 1998).
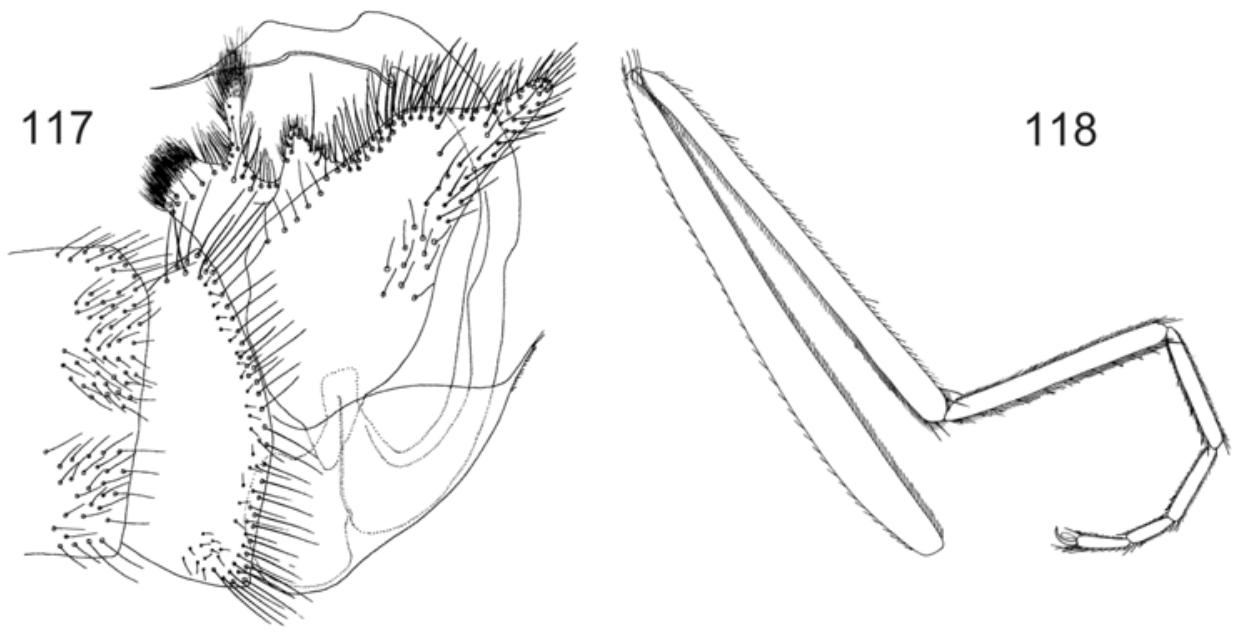

Figs 117-118. Empis (Xanthempis) univittata; 117 - hypopygium, 118 - hind leg.

In Poland it was noted in old faunal inventories only (Palaczyk 1991).

Recorded in the Białowieża Primrval Forest, obtained using the 'yellow pans' method $(\mathrm{MZW})$ in June and July in Topiło forestry in tree crowns and also in undergrowth.

\section{Empis (Xanthempis) aequalis Loew, 1867}

(Fig. 119)

The species is noted only in Germany, the Czech Republic, Austria and northern Italy (Engel 1938-1956, Chvála, Wagner 1989, Pesarini et al. 1995, Chvála 1996, Barták \& Roháček 1999).

In Poland it was noted in old faunal inventories only (Palaczyk 1991) and also indicated by Chvála and Wagner (1989).

One male was captured 19 June 1988 in the Gorce Mts in bushes near the Kamienica stream at the height of about $800 \mathrm{~m}$ a.s.l. In Poland occurs the northern geographical limit of this species. 


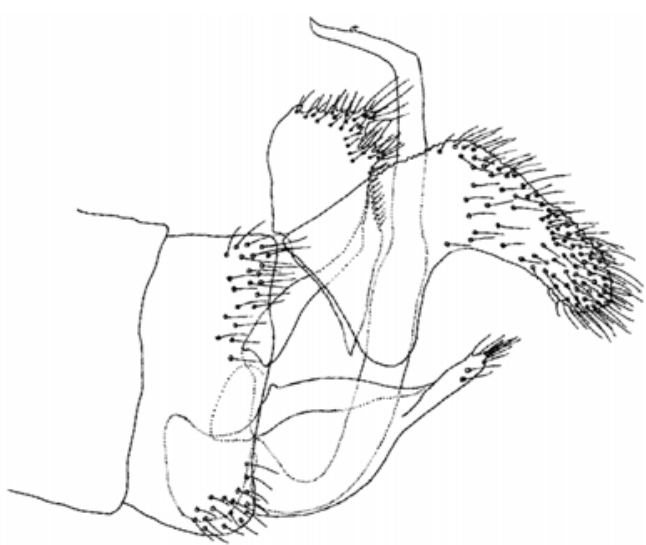

Fig. 119. Empis (Xanthempis) aequalis, hypopygium.

\section{Empis (Xanthempis) trigramma Wiedemann, 1822}

(Fig. 120)

The species is widely distributed in Europe, from Portugal and the British Isles to Ukraine, known from Lithuania and the north-west region of Russia, not reported only in northern and middle Scandinavia (Engel 1938-1956, Collin 1961, Wéber 1981, Chvála \& Wagner 1989, Ceianu 1992, Wehlitz 1992, Chvála 1980, 1994, 1996, Chvála et al.1998, Meyr \& Filipinski 1998, Preston-Mafham 1999, Chvála \& Barták 2000, Grootaert et al. 2001, Plant 2003).

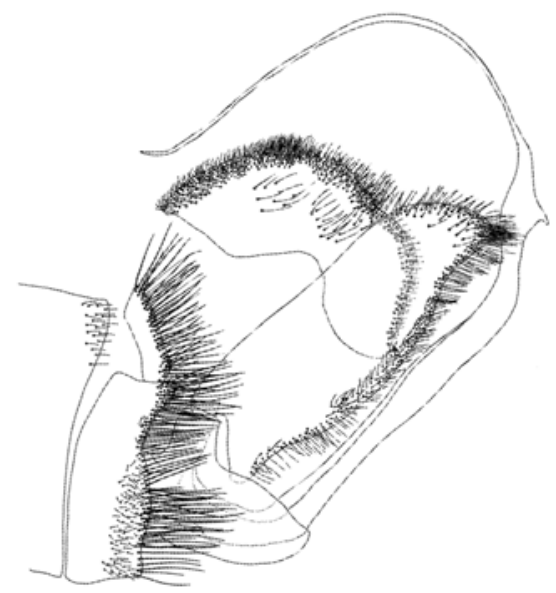

Fig. 120. Empis (Xanthempis) trigramma, hypopygium.

In Poland it was noted in old faunal inventories (Palaczyk 1991) and also in the Białowieża Primeval Forest (Palaczyk 2001), the Bieszczady Mts at the height of $750 \mathrm{~m}$ a.s.l. (Klasa et al. 2000) and also in the massive of the Babia Mount at the height of 600-900 m a.s.1. (Palaczyk \& Klasa 2003). 
Recorded in May and June in the Roztocze Region, in the botanic garden in Łódź (leg. K. Kowalczyk), the Borecka Forest, the Radziejowice village near Warsaw, using the 'yellow pans' method (MZW), in tree crowns, in the meadows near the upper Widawka River and in the Świetokrzyskie Mts in bushes growing on the banks of streams and rivers (leg. J. Wiedeńska).

\section{Empis (Xanthempis) punctata Meigen, 1804}

(Fig. 121)

The species occurs in all Europe together with the British Isles and Scandinavia with the exception of southern regions (Engel 1938-1956, Collin 1961, Chvála \& Wagner 1989, Chvála 1994, 1996, Pesarini et al. 1995, Chvála et al. 1998, Grootaert et al. 2001, Plant 2003).

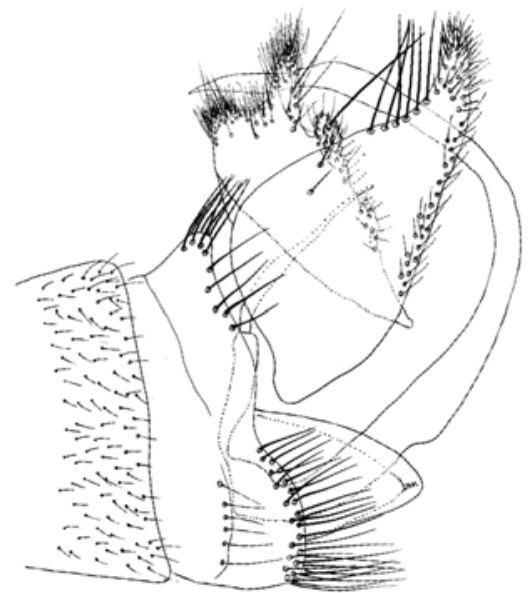

Fig. 121. Empis (Xanthempis) punctata, hypopygium.

In Poland it was noted in old faunal inventories only (Palaczyk 1991).

Recorded in the Kampinoski National Park on the affluent of the Olszowiecki Channel, were one male and two females were captured 5 June 1984.

\section{Empis (Xanthempis) digramma Meigen, 1835}

(Fig. 122)

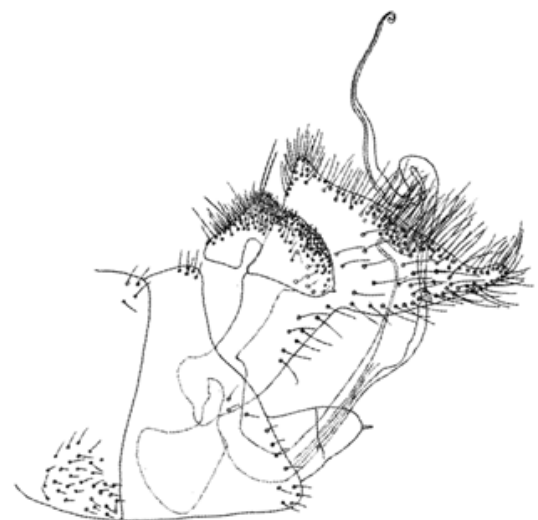

Fig. 122. Empis (Xanthempis) digramma, hypopygium. 
The species is widely distributed in Europe, from the British Isles and southern Scandinavia, Belgium, Holland, Germany, the Czech Republic, Slovakia, Hungary, Austria, Switzerland and Romania to former Yugoslavia and Albania (Engel 1938-1956, Collin 1961, Wéber 1981, Chvála \& Wagner 1989, van der Goot 1989, Ceianu 1992, Chvála 1994, 1996, 1998, Chvála et al. 1998, Barták \& Roháček 1999, Grootaert et al. 2001, Plant 2003).

In Poland it was noted in old faunal inventories (Palaczyk 1991) and also in the massive of the Babia Mount at the height of 700-850 $\mathrm{m}$ a.s.1. (Palaczyk \& Klasa 2003).

One male was collected 12 June 1984 in the Bieszczady Mts in bushes growing on the banks of the Zwór Stream at the height of $800 \mathrm{~m}$ a.s.l. and a second one 13 June 1984 on the bank of the affluent of the San River in the Smolnik village at the height of $550 \mathrm{~m}$ a.s.l.

\section{CONCLUSIONS}

A total of 47 genus Empis species classified in 9 subgenera have been recorded in Poland. This is a number comparable with areas that have been studied in average detail (Collin 1961, Chvála 1994, 1997a, Pesarini et al. 1995, Chvála et al. 1998). However, relying on the number of species recorded in Scandinavia on the one hand, and in the Czech Republic and Slovakia on the other, the total number of genus Empis species that occur in Poland must comprise at least another several dozen. Part of them were mentioned in old faunal inventories and thus confirmed, while 16 species are new for Poland. Numerous species are much widespread in Scandinavia, the British Isles, across western and central Europe, up to northern Italy, Switzerland, France, Romania and northern regions of former Yugoslavia. They are European species, belonging to most subgenera, particularly to the subgenera Xanthempis, Coptophlebia and Empis s. str., while E. picipes, also belonging to this group, occurs also in Greece. Part of the species occurring in the area of northern, central, western and partially eastern Europe are Euro-Siberian species, E. borealis, E. caudatula, E. acinerea, E. bicuspidata, E. planetica, E. dasyprocta, E. punctata. Species occurring in the area increased by the regions of northern Italy, Switzerland and northern areas of former Yugoslavia and Romania are noteworthy. Perhaps they are also European species? The group comprises E. flavitarsis, E. mesogramma, E. gymnopoda, E. melanotricha, E. beckeriana, E. anfractuosa, E. aequalis and E. filata, while E. cincinnatula, E. apfelbecki and E. genualis seem to be Mediterranean species. The northern limit of their occurrence range probably runs across Poland, similarly as it is in the case of alpine species, occurring in the Alps, Pyrenees and Eastern Carpathians (E. alpicola). Only two species are widespread in whole Europe and in most of the Palearctic. These are E. tessellata, a species covering by its occurrence range Japan and northern Africa, and E. nigripes, a species of a slightly smaller range, extending only to western Siberia and northern coasts of the Mediterranean Sea.

\section{ACKNOWLEDGMENTS}

I would like to express my gratitude to two anonymous reviewers for their helpful comments. I especially thank Dr Iwona Krysiak for her friendly help during the last phase of preparation of the manuscript to printing.

\section{REFERENCES}

BÄHRMANN R. 1960. Vergleichend-morphologische Untersuchungen der mannlichen Kopulations Organe bei Empididae (Diptera). Beitr. Entomol. 16: 1-256.

BARTÁK M. \& ROHÁČEK J. 1999. The species of the family Empididae (Diptera) of the six peat-bogs in the Šumava Mts (Czech Republic). Acta Univ. Carol. Biol. 43: 7-26.

BAYFIELD N. G. 1994. Effects of prey abundance on swarming of Empis borealis L. (Diptera, Empididae) in north-east Scotland. Entomol. Gaz. 45: 59-67. 
CEIANU I. 1992. Contribution to the knowledge of superfamily Empidoidea (Diptera) in Romania. I. Trav. Mus. Hist. nat. «Grigore Antipa» 32: 17-48.

ChVÁla M. 1978. The modified mating behaviour of Empis albicans Meig. (Diptera, Empididae), with notes on the presumed origin of prey presentation. Dipt. Bohemosl.1: 55-67.

ChVÁla M. 1980. Swarming rituals in two Empis and one Bicellaria species (Diptera, Empididae). Acta Entomol. Bohemoslov. 77: 1-15.

ChVÁla M. 1981. Empididae (Insecta: Diptera) from southern Spain, with descriptions of twenty new species and notes on Spanish fauna. Steenstrupia 7(6): 113-177.

ChVÁla M. 1983. The Empidoidea (Diptera) of Fennoscandia and Denmark. II General Part. The Families Hybotidae, Atelestidae and Microphoridae. Fauna Entomol. Scand. 12: 1-279.

CHVÁlA M. 1990. Mating swarms of Diptera, effective ethological isolating mechanisms. Acta Univ. Carol. Biol. 33 : 449-454.

ChvÁla M. 1991. Empididae (Diptera) of Finland: The Empis subgenus Empis and Coptophlebia. Entomol. Fenn. 2: $79-86$.

ChVÁla M. 1994. The Empidoidea (Diptera) of Fennoscandia and Denmark. III. Genus Empis. Fauna Entomol. Scand. 29: 1-192.

CHVÁla M. 1996. Clasification and phylogeny of European Empis subgenus Xanthempis Bezzi (Diptera, Empididae). Studia Dipterologica 3: 3-18.

ChVÁla M. 1997a. Additions and corrections to the faunistic data of the family Empididae (Diptera). Folia Fac. Sci. Nat. Univ. Masaryk. Brun. Biol. 15: 43-46.

Chvála M. 1997b. Empididae. In: Chvála M. (ed.), Check list of Diptera (Insecta) of the Czech and Slovak Republics. Karolinum - Charles University Press, Prague, 48-51.

CHVÁla M. 1998. Empididae. In: RoZkoŠnÝ R. \& VAŇHARA J. (eds), Diptera of the Pálava Biosphere Reserve of UNESCO, I. Folia Fac. Sci. Nat. Univ. Masaryk. Brun. Biol. 99: 161-167.

ChVÁla M. 1999. Revision of Palaearctic species of the Empis subgenus Polyblepharis (Diptera: Empididae), with descriptions of fourteen new species. Acta Univ. Carol. Biol. 42: 113-225.

Chvála M. \& Vrtiskova-Bouskova J. 1989. Fauna of the Empididae and Hybotidae (Diptera) of Prague. Acta Univ. Carol. Biol. 31: 373-405.

Chvála M. \& Wagner R. 1989. Family Empididae. In: Soós A \& PAPP L. (eds), Catalogue of Palearctic Diptera. 6: 228-336. Akademiai Kiado, Budapest.

ChVÁla M. \& BARTÁK M. 2000. Empididae. In: BARTÁK M. \& VAŇHARA J. (eds), Diptera in an industrially affected region (North-Western Bohemia, Bílina and Duchcov Environs), I-II. Folia Fac. Sci. Nat. Univ. Masaryk. Brun. Biol. 104: 175-181.

ChvÁla M., BArtÁK J., Beuk P., Merz B. \& Wagner R. 1998. Empididae. In: Fauna Helvetica. Diptera - Checklist. Schweiz. Entomol. Ges. 6: 228-336.

Collin J. E. 1961. Empididae. British Flies 6; 1. Tachydrominae: 1-119, 2. Hybotinae, Empidinae (except Hilara): 223-551, 3. Empidinae (Part) and Hemerodrominae: 555-782.Cambridge University Press, Cambridge.

ENGEL O. 1938-1956. Empididae. In: Lindner E. (ed.), Die Fliegen der palaearktischen Region. 4: 1-434.

FREY R. 1945. Tiergeographische Studien uber die Dipteren-Fauna der Azoran. I.Verzeichnis der bisher von den Azoren bekanntnen Dipteren. Commentat. Biol. 8(10): 1-114.

Grootaert P., Pollet M. \& Maes D. 2001. A Red Data Book of Empidid Flies of Flanders (northern Belgium) (Diptera, Empididae s. 1.): Constraints and possible use in nature conservation. J. Insect Conserv. 5 (2): $117-129$.

Grootaert P., Shamshev I., Földvári M. \& Menten J. 2004. Update of the Belgian list of Empis s. str. species (Diptera, Empididae) with some new records for the Belgian fauna. Bulletin Soc. R. Belge Entomol. 140: $96-100$.

GRUHL K. 1955. Neue Beobachtungen an Schwarm und Tanzgesellschaften der Dipteren (Dipt.). Dtsch. Entomol. Z. 2: 332-353.

HipPA H., Koponen S. \& OSMONEN O. 1981. Flower visitors to the clouddberry (Rubus Chamaemorus L.) in northern Fennoscandia. Rep. Kevo Subarct. Res. St. 17: 44-54.

Hobвy B. M. \& Sмiтн K. G. V. 1961. The bionomics of Empis tesselata F., (Dipt., Empididae). Entomol. Mon. Mag. 97: $2-10$.

Hoвby B. M. \& Sмiтн K. G. V. 1962. The bionomics of Empis opaca Mg. (Dipt., Empididae). Entomol. Mon. Mag. 97: 204-208.

Klasa A., PalaczyK A. \& Soszyński B. 2000. Muchówki (Diptera) Bieszczadów. In: PawŁowski J. (ed.), Monografie Bieszczadzkie, Bezkręgowce Bieszczadów Zachodnich ze szczególnym uwzględnieniem Bieszczadzkiego Parku Narodowego, part II, 8: 334-339. Ustrzyki Dolne, 369 pp.

McAlpine J. E., Peterson B. V., Shewell G. E., Teskey H. J., Vockeroth J. R., Wood D. M. 1981. Manual of nearctic Diptera. Research Branch Agruculture Canada, Monograph 27: 1-674. 
MEYER H. \& SPETH S. 1995. Empididae (Diptera: Dolichopodidae, Empididae, Hybotidae) aus emergenzfangen eines Norddeutschland Tieflandbachsystems In Bereich von Osterau und Rodenbek (Holsteinische Vorgeest). Mitt. Dtsch. Ges. Allg. Angew. Ent. 9: 649-655.

MEYER H. \& FILIPINSKI B. 1998. Empidoidea (Diptera: Dolichopodidae, Empididae, Hybotidae, Microphoridae) aus Emergenzfangen von zwei Seeausflussen (Oberer und Unterere Schierenseebach) in Norddeutschland (Holsteinische Jungmorane). Studia Dipterologica 5 (1): 123-144.

PALACZYK A. 1991. Empididae. In: RAZOwSKI J. (ed.), Checklist of animals of Poland, vol.II, part XXXII/25-29 Insecta: Trichoptera - Siphonaptera, pp. 142-147 PWN, Wrocław, 342 pp. [In Polish with English comments]

PALACZYK A. 2001. Empididae-Microphoridae. In: GutOWSKi J. M. \& JAROSZEWICZ B. Catalogue of the fauna of Białowieża Primeval Forest, pp. 282-284, IBL, Warszawa, 403 pp.

PAlaczyK A. \& Klasa A. 2003. Diptera of the Babia Góra Massif. In: WoŁoszyn B. W., Woloszyn D., Celary W. (eds), Fauna of Mt. Babia Góra, Poland. Kraków 2003, pp. 305-357. Komitet Ochrony Przyrody PAN, 489 pp. [In Polish with English abstract and summary]

Pesarini F., RAFFone G. \& Wagner R. 1995. Empididae. In: Minelli A., Ruffo S. \& S. LA Posta (eds), Checklist della specie della fauna Italiana. Diptera Empidoidea, Bologna (Calderini) 69: 1-23.

Plant A.R. 2003. Phenology of Empididae and Hybotidae (Diptera) in Great Britain. Dipterists Digest 10: 13-30.

Preston-Mafham K. G. 1999. Courtship and mating in Empis (Xanthempis) trigramma Meig., E. tesselata F. and E. (Polyblepharis) opaca F. (Diptera: Empididae) and the possible implications of „cheating” behaviour. J. Zool. 247: 239-246.

SCHUMANN H., BÄHRMANN R. \& STARK A. 1999. Entomofauna Germanica 2. Checkliste der Dipteren Deutschlands, $1-354$.

Sмiтн K. G. V. 1997. Family Empididae. Australian/Oceanian Diptera. Catalog-web version, hbs. Bishopmuseum. org./aocat/empididae html-32.

STRAKA V. 1981. Prispevok k poznaniu vyskytu rovnosvych mucjh a okaniek (Diptera, Orthorrhapha, Archischiza) na Slovensku. Acta Rer. Natur. Mus. Nat. Slov. 27: 77-88.

SVEnSSON G., PETERSSON E. \& ForSGREN E. 1989. Why do males of the dance fly Empis borealis refuse to mate? The importance of female age and size. J. Insects Behavior 2(3): 387-395.

SVENSSON G. \& PETERSSON E. 1992. Why insects swarm: testing the models for lek mating system on swarming Empis borealis females. Behav. Ecol. Sociobiol. 31: 253-261.

SVEnSSON G. \& PETERSSON E. 1994. Mate choice tactics and swarm size: a model and a test in a dance fly. Behav. Ecol. Sociobiol. 35: 161-168.

SZADZIEwSKA M. 1977. Geofilne muchówki (Diptera) rezerwatu „Las Piwnicki” koło Torunia. Acta Univ. Nicolai Copernici Biol., Toruń 19: 107-115.

SZADZIEWSKI R. 1983. Flies (Diptera) of the saline habitats of Poland. Pol. Pismo Entomol. 53: 31-76.

SYROVÁtKA O. 1980. Revision of the subgenus Empis s.str. (Pterempis Bezzi) (Diptera: Empididae) in Czechoslovakia. Acta Univ. Carol. Biol. 1977: 423-427.

SyrovátKa O. 1991. Revision of H. Loew's and T. Becker's types of Empis s. str. species (Diptera, Empididae) in the Berlin and St. Petersburg Museums. Mitt. Zool. Mus. Berl. 67(2): 225-278.

SyrovátKa O., ChVÁla M. 1986. Revision of J. W. Meigen's types of Empis s. str. (Diptera: Empididae) of the Paris Museum, with an appaendix on Macquart's species. Vestn. Cesk. Spol. Zool. 50: 231-239.

TRÉHEN P. 1971. Recherches sur les Empidides a larves edaphiques. Dissertation, Universite de Rennes, C, 133 (44): 1-280.

Tulowitzki I., Meyer H., Irmler U., Tischler Th. \& Reinke H.-D. 1999. Die Arthropodenfauna im Untertrabereich und am Dummersdorfer Ufer (Schleswig-Holstein). Faun.Oekol. Mitt. 7: 41-480.

VAN DER GoOT V. S. 1989. De dansvliegen van het geslacht Empis in Nederland (Diptera: Empididae). Ent. Ber. Amsterdam 49: 1173-184.

VAN DER GOOT V. S. 1990. Onderzok near het voorkomen van de dansvlieg Empis aestiva in de bossen van de provincie Flevoland (Diptera: Empididae). Entomol. Ber. (Amst). 50 (8): 97-98.

VOLKART H. D. 1991. Die Insektenfauna des Hochmoores Balmoos bei Hasle, kanten Luzern, XXV. Diptera 3 : Hybotidae und Empididae (Tanzfliegen). Entomol. Ber. Luzern 25: 51-57.

WATERS S.B. 1989. A Cretaceous dance fly (Diptera: Empididae) from Botswana. Syst. Entomol. 14: $233-241$.

WÉBER M. 1975. Tancoslegyek-Empididae. Fauna Hungariae, XIV, 13, Akadémiai Kiadó, Budapest, 220 pp.

WÉBER M. 1981. The empidid fauna of the Hortobagy National Park (Diptera), The Fauna of the Hortobagy National Park, Budapest, separatum: 207-211.

Wehlitz J. 1992. Zur Tanzfliegen-Fauna von Koln (Diptera: Microphoridae, Hybotidae, Empididae). Decheniana Beih. 31: 341-378.

YAng D., Grootaert P. \& Horvat B. 2004. A new species of Dolichocephala, with a key to the species from China (Insecta: Diptera, Empididae). Aquatic Insects, 26: 215-219.

YOUNG J. H. \& MERRITT D. 2003. The ultrastructure and function of the silk-producing basitarsus in the Hilarini (Diptera: Empididae). Arthropod structure and development 32: 157-165. 
[Morfologia, biologia, fenologia i występowanie rodzaju Empis Linnaeus (Empididae, Diptera) na terenie Polski]]

W pracy przedstawiona została morfologia postaci uskrzydlonych, a także larw i poczwarek, stopień poznania zwłaszcza w Polsce, systematyka, biologia i fenologia rodzaju Empis (Empididae, Diptera). Morfologia larw i poczwarek poznana jest w niewielkim jedynie stopniu i pod tym względem niniejsze opracowanie jest $\mathrm{w}$ pewnym stopniu uzupełnieniem istniejącej luki. Muchówki z rodzaju Empis są drapieżne, a część z nich odżywia się także nekatrem i pyłkiem kwiatowym. Charakteryzują się one skomplikowanym zachowaniem godowym polegającym między innymi na przekazywaniu przez samce $\mathrm{w}$ trakcie lotu odbywającego się nad powierzchnią wody i poprzedzającego kopulację tzw. „prezentu ślubnego", najczęściej są to drobne owady lub ziarnka pyłku. W związku z tym nogi samców wielu gatunków $\mathrm{z}$ w/w rodzaju są owłosione grubymi i długimi włosami oraz bardzo mocnymi szczecinami, a niektóre człony stóp są znacznie grubsze od pozostałych. Muchówki z rodzaju Empis odgrywają istotną rolę również przy zapylaniu kwiatów.

Stwierdzono występowanie w Polsce 47 gatunków z rodzaju Empis, które reprezentują 9 podrodzajów. Jest to liczba porównywalna do liczby gatunków innych, w miarę szczegółowo zbadanych obszarów. Prawdopodobnie, pełna lista gatunków z rodzaju Empis występujących w Polsce obejmuje jeszcze co najmniej kilkadziesiąt gatunków. Informacje na temat występowania tego rodzaju na obszarze Polski pochodzą $\mathrm{z}$ opracowań zbiorczych poświęconych muchówkom niektórych obszarów, a znaczna część stwierdzonych obecnie $\mathrm{z}$ obszaru Polski gatunków była wymieniana jedynie w pochodzących z XIX wieku i mających historyczne przede wszystkim znaczenie spisach faunistycznych i została obecnie po raz pierwszy od tamtego czasu potwierdzona. 16 gatunków jest nowych dla Polski. Wyróżniono kilka grup gatunków: europejskie, eurosyberyjskie, charakterystyczne dla Europy Środkowej oraz gatunki śródziemnomorskie, których północna granica zasięgu przebiega przez Polskę. 